\title{
Guidance Note for Fund Staff on the Treatment and Use of SDR Allocations
}




\section{INTERNATIONAL MONETARY FUND}

\section{GUIDANCE NOTE FOR FUND STAFF ON THE TREATMENT AND USE OF SDR ALLOCATIONS}

IMF staff regularly produces papers proposing new IMF policies, exploring options for reform, or reviewing existing IMF policies and operations. The following documents have been released and are included in this package:

- The Guidance Note prepared by IMF staff and completed on July 28, 2021.

The IMF's transparency policy allows for the deletion of market-sensitive information and premature disclosure of the authorities' policy intentions in published staff reports and other documents.

Electronic copies of IMF Policy Papers are available to the public from

http://www.imf.org/external/pp/ppindex.aspx

\section{International Monetary Fund Washington, D.C.}

(c) $20[x x]$ International Monetary Fund 


\section{INTERNATIONAL MONETARY FUND}

July 28, 2021

\section{GUIDANCE NOTE FOR FUND STAFF ON THE TREATMENT} AND USE OF SDR ALLOCATIONS

\section{EXECUTIVE SUMMARY}

This Note provides guidance for staff on the treatment and use of allocations of Special Drawing Rights (SDRs). It presents a consistent framework for IMF country teams to assess the macroeconomic implications of the SDR allocation at the country level, covering the following areas:

- Statistical and accounting treatment. Members should present and disseminate their SDR data in line with the best practices to which they subscribe. Under the latest recording guidelines in the Balance of Payments and International Investment Position Manual-Sixth Edition (BPM6), both gross international reserves and external long-term debt liabilities would increase with the new SDR allocation. Net international reserves (NIR) would also normally be expected to increase, while net foreign assets (NFA) do not change.

- General macroeconomic implications and advice. Member countries can use their newly allocated SDRs unconditionally. A central policy question is whether the policy space provided by the allocation should be retained or used, either partially or entirely. This decision should reflect many considerations, including the economic conjuncture and the stage of the COVID-19 pandemic, the adequacy of reserves, the availability of fiscal and monetary policy space, domestic and external debt sustainability and financial stability, financing constraints, and other country-specific factors.

In the circumstances prevailing at the time of the 2021 general allocation of SDRs, given the exceptional nature of the COVID-19 shock, countries that need to prioritize the response to the crisis should act flexibly and swiftly, including by potentially using the policy space provided by the SDR allocation to fight the pandemic. For countries exiting the emergency phase of the COVID-19 pandemic, the policy advice should shift to supporting a resilient, inclusive, sustainable, and green recovery. Staff should advise member authorities to use SDRs consistent with macroeconomic sustainability and in a transparent manner, and to not delay needed macroeconomic adjustment, reforms, and debt restructuring, nor prolong unsustainable macroeconomic policies. 
- Debt sustainability analyses. The SDR allocation, by itself, does not negatively impact members' debt sustainability and could even enhance it by strengthening reserve buffers and resilience. If the authorities use the policy space provided by the allocation, the overall impact of the SDR allocation on debt sustainability depends on how the allocation is used. This updated guidance supersedes prior staff guidance related to debt sustainability analyses, including the $2018 \mathrm{Debt}$ Sustainability Framework for Low-Income Countries (LIC-DSF).

- Transparency and accountability. Several elements of the Fund's work on transparency are relevant for the use of SDRs, including the Fund's Safeguards Assessment Policy (SAP), and fiscal transparency. Staff can leverage these frameworks to encourage transparency and accountability in the use of SDRs.

The Fund already publishes quarterly SDR holdings by members and will further enhance transparency in the use of SDRs by publishing those holdings by aggregate category. It will also publish the Board paper Annual Update on SDR Trading Operations. Two years after the allocation, staff will prepare an ex-post report on the use of SDRs.

- Reserve management. Like other reserve assets, SDR holdings expose central banks to certain financial risks, which need to be understood, measured, and appropriately managed. These include liquidity, currency, interest rate, and credit risks.

- Implications for Fund-supported programs. The SDR allocation will generally require an update of Fund-supported programs, particularly a fresh look at reserve adequacy and macroeconomic policies. The following key principles apply: (i) different domestic arrangements for recording SDRs should not lead to different macroeconomic assessments and advice across countries, although possible constraints on the use of SDRs arising from institutional arrangements would need to be considered; (ii) direct program limits on the use of SDR holdings would be inconsistent with their status as an unconditional reserve asset, but program targets may indirectly result in limits via fiscal and monetary conditionality; (iii) the degree to which program targets should be adjusted following the SDR allocation depends on an assessment of reserve adequacy and other relevant macroeconomic considerations; and (iv) the allocation should not delay needed macroeconomic adjustments and reforms nor substitute for debt restructuring, if debt is assessed as unsustainable. Access to financing under Fund arrangements will continue to be guided by the established criteria-including the member's balance of payment need, ability to repay the Fund, and outstanding Fund credit and track record-while considering the impact of the SDR allocation on members' macroeconomic frameworks. 
Approved By

Ceyla Pazarbasioglu
Prepared by the Strategy, Policy, and Review Department in collaboration with the Finance, Legal, Monetary and Capital Markets, and Statistics Departments. The team was led by C. Tovar (SPR) and comprised by N. Shenai (team lead), M. Takebe, Y. Wu, T. Zheng, and E. Pondi Endengle; D. Kim, W. McGrew, L. Kohler; H. Poirson Ward, S. Rodriguez, M. Hengge; M. Saenz, T. Willems; K. Fletcher (all SPR); H. Hatanpaa, G. Everaert, M. Nkusu, M. Manno, J. Mburu, V. Kurcova, E. Okosodo, A. Nakafeero, F. Moreau, and Z. Tan (all FIN); H. Pham, A. Rosha, and C. Thiemann (all LEG); A. Qureshi (MCM); and B. Cotto, M. Dinenzon, and V. Josyula (all STA). N. Hallmark (SPR) provided research assistance, while T. Garicoche and D. Miller Passos Da Silva helped prepare the report. A. Corbacho (SPR) provided overall guidance under the supervision of K. Kostial (SPR).

\section{CONTENTS}

STATISTICAL AND ACCOUNTING CONSIDERATIONS

GENERAL MACROECONOMIC IMPLICATIONS AND POLICY ADVICE 12

IMPLICATIONS FOR DEBT SUSTAINABILITY ANALYSES 18

PROMOTING TRANSPARENCY AND ACCOUNTABILITY IN THE USE AND THE REPORTING OF SDRS

IMPLICATIONS FOR CENTRAL BANKS' RESERVE MANAGEMENT $\underline{28}$

IMPLICATIONS FOR FUND-SUPPORTED PROGRAMS $\underline{30}$

\section{BOXES}

1. Key Legal Considerations Related to the Treatment and Use of SDR Allocation 11

2. Modifications to Past Guidance for DSAs $\underline{23}$

FIGURE

1. Selected Interest Rates 17

\section{TABLES}

1. Uses of SDR Holdings - Implications for the Public DSA 
2. Publicly Available Information on SDR Allocations and Holdings, Trading, and VTAs 26

3. Template for Reporting Quarterly Changes in Participants' SDR Holdings

\section{ANNEXES}

I. Additional Statistical Considerations $\underline{33}$

II. Reconstitution Requirements for SDR Holdings $\underline{36}$

III. SDR Department $\underline{38}$

IV. Useful Tools and Links to SDR Resources for Staff $\underline{43}$

References 44 


\section{Abbreviations and Acronyms}

BPM6 Balance of Payments and International Investment Position Manual—Sixth Edition

BOPSY Balance of Payments Statistical Yearbook

$\mathrm{CB}$

Central Bank

CCRT Catastrophe Containment and Relief Trust

DSA Debt Sustainability Analysis

EDS External Debt Statistics

ESS External Sector Statistics

FTC Fiscal Transparency Code

FTE Fiscal Transparency Evaluation

GFS Government Finance Statistics

GFSM Government Financial Statistics Manual

GRA General Resources Account

HIPC Heavily Indebted Poor Countries

IFS International Financial Statistics

IFRS International Financial Reporting Standards

IIP International Investment Position

IRFCL International Reserves and Foreign Currency Liquidity

JEDH Joint External Debt Hub

LIC Low-Income Country

LIC-DSF Debt Sustainability Framework for Low-Income Countries

MAC-DSA Debt Sustainability Analysis for Market-Access Countries

MFS Monetary and Financial Statistics

MFSMCG Monetary and Financial Statistics Manual and Compilation Guide

MoF Government Agency (e.g., Ministry of Finance)

NAFA Net Acquisition of Financial Assets

NFA Net Foreign Assets 
NIL Net Incurrence of Liabilities

NIR Net International Reserves

QEDS Quarterly External Debt Statistics

QPSDS Quarterly Public Sector Debt Statistics

PRGT Poverty Reduction and Growth Trust

RAP Reserve Asset Portion

SAP Safeguards Assessment Policy

SDRs Special Drawing Rights

STA International Monetary Fund Statistics Department

TMU Technical Memorandum of Understanding

VTA Voluntary Trading Arrangements 


\section{INTRODUCTION}

1. In August 2021, the IMF implemented a general allocation of SDRs equivalent to about US $\$ 650$ billion (SDR 456 billion). ${ }^{1}$ The main purpose of the allocation is to help meet the longterm global need to supplement existing reserve assets in a manner that will avoid economic stagnation and deflation as well as excess demand and inflation. In doing so, the SDR allocation helps promote the attainment of the Fund's purposes as spelled out in the Articles of Agreement. ${ }^{2}$

2. The Articles of Agreement determine that SDRs are allocated to Fund members that are participants in the SDR Department-currently all 190 Fund members (Article XV). ${ }^{3}$ Per Article XVIII, Section 2(b), SDRs are distributed in proportion to participants' paid Fund quota shares. ${ }^{4}$ The allocation was made uniformly at 95.8455025357 percent of members' quotas. ${ }^{5}$ Thus, of the US $\$ 650$ billion, about US $\$ 375$ billion (SDR 264 billion) were allocated to advanced economies, while US $\$ 275$ billion (SDR 193 billion) of the allocation were allocated to emerging market and developing countries, including about US\$21 billion (SDR 15 billion) to low-income countries (LICS).

\section{Members enjoy a large degree of freedom in how to manage the SDRs allocated to} them, including to what extent central banks are involved in their management and whether the budget can directly use them for budget support. Institutional arrangements among members differ in terms of holding SDRs. For many members, SDRs are administered by the central bank. Some of these central banks can on-lend resources related to the SDRs to the government, while others cannot. From the IMF's perspective, SDRs are allocated and held by the member and instructions for its use come through the fiscal agency of the member. The guidance set out in this Note normally applies to all members irrespective of the institutional arrangements but in a number of areas, institutional arrangements are taken into account in the guidance on how to treat SDRs and their use in relevant areas of policy advice.

\section{The SDR allocation is expected to have important macroeconomic benefits for the} global economy and for member countries. It is a unique instrument that supports all IMF members, boosts reserves, helps build confidence, and sends a powerful signal of a cooperative multilateral response to the COVID-19 crisis. The provision of unconditional reserves will help liquidity-constrained countries address the fallout from the COVID-19 crisis by limiting the need for adjustment through contractionary and/or distortionary policies, and by allowing greater scope for a

\footnotetext{
${ }^{1}$ The SDR exchange rate of reference is 0.702283 SDR per USD as of July 1, 2021 (the date of The Chair's Summing Up Proposal for a General Allocation of Special Drawing Rights Executive Board Meeting 21/65). See IMF (2021a).

${ }^{2}$ Article I sets out the purposes of the Fund, while Article XVIII lays out the legal framework for an SDR allocation.

${ }^{3}$ Since all IMF member countries are SDR Department participants, henceforth this Note will interchangeably refer to SDR Department participants as members or member countries.

${ }^{4}$ Article XVIII, Section 2(b) provides that "the rates at which allocations are to be made shall be expressed as percentages of quotas on the date of each decision to allocate" and that "the percentages shall be the same for all participants."

${ }^{5}$ See IMF (2021b).
} 
countercyclical response. It will also provide scope for spending on members' crisis response, helping to protect the most vulnerable and reduce the risk of extended scarring. Overall, the allocation is expected to foster systemic stability and global resilience.

\section{At the same time, the SDR allocation entails risks that need to be considered and}

managed. Recipient countries could delay needed macroeconomic adjustment and reforms or use SDRs without fully considering the potential costs and risks. These include, among others, the quarterly interest charges at variable interest rates associated with the use of SDRs and the need to monitor closely SDR holdings to ensure timely settlement of SDR-denominated obligations to the Fund. Additionally, risks arising from making an inadequate use of SDRs could be high in countries with unsustainable debt or weak governance. This further underscores the need for enhanced efforts to strengthen transparency and accountability. Members should not use SDRs to maintain unsustainable policies. Doing so may lead to costs, including by undermining members' ability to secure adequate access to future financing. ${ }^{6}$ These risks can be mitigated in part through appropriate Fund advice, both in surveillance and program engagement with the membership, as was done in the context of the 2009 allocation.

\section{Against this background, this Note provides guidance on the treatment and use of the} general allocation of SDRs. Executive Directors asked staff to prepare a Guidance Note to help country teams develop policy advice consistent with macroeconomic sustainability. ${ }^{7}$ This Guidance Note provides a consistent framework for assessing the macroeconomic implications of the allocation at the country level, clarifies its statistical and accounting treatment, discusses the differences in institutional arrangements, and reviews its implications for debt sustainability analyses and reserve management. Reflecting the global economic and policy setting, the Note provides guidance both in surveillance and program contexts.

\section{This Note also outlines principles that can enhance transparency and accountability in} the use of SDRs. It reflects members' request to enhance transparency and accountability in the reporting and use of SDRs, while preserving the unconditional nature of SDRs as reserves. ${ }^{8}$ To this end, this Guidance Note highlights how country teams can leverage existing Fund frameworks to provide advice on transparent use of SDRs, including the set of principles and best practices laid out in the IMF's Safeguards Assessment Policy and fiscal transparency frameworks. It also lays out measures to enhance the publication of information relating to the use of SDRs.

\footnotetext{
${ }^{6}$ By using the policy space provided by the SDR allocation imprudently (e.g., to pursue unsustainable policies, delay needed macroeconomic adjustment and reforms, or in a non-transparent manner), some members could perpetuate imbalances (or the perception of doing so), which could adversely impact investors' risk perception and their ability to access market financing at a reasonable cost. Despite these risks, ex-post analyses of the 2009 SDR allocation found that there was "little evidence of widespread moral hazard" in the use of the SDR allocation. For further elaboration, see IMF (2018a). Staff advice will be important to mitigate this risk.

${ }^{7}$ See Chair's Summing up for "Proposal for a General Allocation of Special Drawing Rights," July 12, 2021.

${ }^{8}$ See April 8 Communiqué of the International Monetary and Financial Committee.
} 
8. The Guidance Note is organized as follows. The next section describes statistical and accounting considerations. The third section provides guidance on macroeconomic implications and related policy advice. The fourth section explains the treatment of SDR allocations in debt sustainability analyses, while the fifth section presents staff's advice on promoting transparency and accountability in the use and reporting of SDRs. The sixth section outlines implications of the allocation for reserve management, and the seventh and final section elaborates on the implications of SDRs for Fund-supported programs. The Annexes provide additional information and operational details on statistical considerations, the SDR reconstitution mechanism, the SDR Department, and useful SDR tools for Fund staff.

\section{STATISTICAL AND ACCOUNTING CONSIDERATIONS}

9. The Articles of Agreement do not prescribe the institutional arrangements for holding SDRs by members, including specific accounting treatment for SDR allocations. Members are thus not obliged under the Articles to hold SDRs under specific institutional arrangements nor to follow a specific accounting framework or methodology, and institutional arrangements differ widely. Regardless of the domestic institutional arrangements for holding SDRs and the specific accounting treatment followed by members or the entity that acts as a member's fiscal agent, from the perspective of the SDR Department and the Fund, the obligations and rights arising under the Articles of Agreement from members' participation in the SDR Department-including those related to the use of SDR allocations - are obligations and rights of the relevant member and not of the fiscal agent or other entity of the member involved in managing a member's SDR position (see Box 1).

\section{Members that voluntarily subscribe to specific statistical best practices would be} expected to present and disseminate their data in line with the best practices to which they subscribe. These best practices, however, do not specify in which of the member's domestic institutions SDRs should be recorded. Domestic arrangements for holding SDRs and the accounting treatment should follow all domestic legal and institutional frameworks.

\section{Under the latest accounting guidelines, both gross international reserves and} long-term debt liabilities increase with the new SDR allocation. Following the Balance of Payments and International Investment Position Manual-Sixth Edition (BPM6), new allocations of SDRs to IMF members are recorded as increases in gross international reserves (holdings of SDRs), with an equal increase in the members' long-term debt liabilities to the participants of the SDR Department (allocations of SDRs). ${ }^{9}$ As elaborated in the section on debt sustainability analyses, these

\footnotetext{
${ }^{9}$ Under the 2013 External Debt Statistics (EDS) Guide and the BPM6, SDR allocations are included as a long-term debt liability in the gross external debt statistics and the international investment position (IIP). In the IIP, SDRs are also shown as a long-term reserve-related liability, which is a supplementary item. The BPM6 provides a definition of reserve-related liability as those foreign currency liabilities of the monetary authorities that can be considered as direct claims by nonresidents on the reserve assets of an economy, and SDR allocations can be considered a long-term reserve-related liability. It classifies reserve-related liabilities to nonresidents on a remaining maturity basis and by debt instrument as follows: (i) short-term reserve-related liabilities (memorandum items), and (ii) long-term reserve-related liabilities (supplementary items). The debt-related liability and reserve-related liability are different concepts. Long-term debt liabilities can include a wide variety of financial instruments, such as long-term (continued)
} 
long-term liabilities (allocations of SDRs) should not be included in the stock of debt for assessing debt sustainability. ${ }^{10}$ The holdings and allocations should be reported in gross terms, rather than netted against each other. This treatment is consistent across macroeconomic statistics manuals (see Annex I). ${ }^{11}$ In the majority of member countries, where the SDR positions are recorded as assets and liabilities in the central bank's balance sheet, the SDR holdings would directly increase central bank gross international reserves. ${ }^{12}$ There may be cases where SDRs are recorded on the balance sheet of a government agency rather than the central bank. In these cases, SDR holdings and allocations would be recorded as financial assets and liabilities of the government agency. ${ }^{13}$ Regardless of where SDRs are recorded, gross international reserves increase with the allocation.

\section{NIR would be expected to increase with the new SDR allocation, provided that long-} term foreign exchange debt liabilities are not subtracted from NIR. The allocation will have no impact on net foreign assets (NFA) because both foreign assets and liabilities increase. But it would increase NIR provided that the member does not subtract long-term reserve-related liabilities from NIR, as is done in a preponderance of cases. ${ }^{14}$

\footnotetext{
loans and debt securities, while reserve-related liabilities are foreign exchange liabilities of the monetary authorities that can be considered as direct claims by non-residents on the reserve assets of an economy. So, not all long-term debt liabilities are reserve-related liabilities, and reserve-related liabilities also include short-term debt liabilities.

${ }^{10}$ The adjustments to Government Finance Statistics (GFS) would help facilitate a consistent Debt Sustainability Analysis (DSA) across countries, independently of whether the SDR positions are recorded in the central bank's or a government agency's balance sheet (see section on DSA).

11 The guidelines were adopted for the BPM6 and the 2008 System of National Accounts in 2008; and subsequent updates for the 2013 External Debt Statistics: Guide for Compilers and Users (2013 EDS Guide), the 2013 International Reserves and Foreign Currency Liquidity: Guidelines for a Data Template (2013 IRFCL Guidelines), the 2014 Government Finance Statistics Manual (GFSM 2014), and the 2016 Monetary and Financial Statistics Manual and Compilation Guide (MFSMCG 2016).

${ }^{12} \mathrm{~A}$ member's positions with the Fund is generally consolidated in the central bank to include both the fiscal and monetary authorities. This results in an augmented central bank balance sheet, identified as the monetary authorities' account. This practice would be consistent with the BPM6 functional concept of monetary authorities, which encompass the central bank (which subsumes other institutional units included in the central bank subsector) and certain operations usually attributed to the central bank but sometimes carried out by other government institutions or commercial banks, such as government-owned commercial banks. See also Annex 4.2 Accounts with the IMF in the MFSMCG 2016. Statistics manuals state that SDR can only be held by the members' monetary authorities (2013 EDS Guide paragraph 3.45 and BPM6 paragraph 5.34) without specifying in which government institution balance sheet the SDRs should be recorded (GFSM 2014 paragraph A3.93).

${ }^{13}$ In some countries, authorities record the SDRs in the government balance sheet and their domestic legislation specifies that a government agency is the ultimate owner of SDRs.

14 There have been a minority of cases in the past in which countries' NIR definitions netted all reserve-related liabilities, regardless of maturity. If this treatment is followed, then the SDR allocation will not result in an increase in NIR. Country teams will need to examine each case to understand which situation applies. It is expected that BPM7-the successor of BPM6-will provide further guidance on the statistical definition of NIR for IMF's surveillance analytical needs and cross-country comparisons.
} 
Box 1. Key Legal Considerations Related to the Treatment and Use of SDR Allocations

Pursuant to the Articles, SDRs are allocated to Fund members that are participants in the SDR Department (Article XV). Regardless of the domestic institutional arrangements for holding SDRs and the specific accounting treatment followed by members or the entity that acts as a member's fiscal agent, from the perspective of the SDR Department and the Fund, the obligations and rights arising under the Articles of Agreement from members' participation in the SDR Department-including those related to the use of SDR allocations-are obligations and rights of the relevant member and not of the fiscal agent or other entity of the member involved in managing a member's SDR position. Regardless of where SDRs are recorded domestically, SDRs are the assets and obligations of the member.

Under Article V, Section 1, each member is to deal with the Fund only through its fiscal agency, and the Fund is to deal with the member only through the same agent. Accordingly, instructions from a member for the transfer of SDRs must be given by its fiscal agency, that is the agency or entity that acts as an intermediary to represent the member in its financial dealings with the Fund (see also Rule G-2 of the Fund's Rules and Regulations).

The Articles of Agreement do not prescribe a specific accounting treatment for SDR allocations. Accordingly, members are not obliged under the Articles to follow a specific accounting framework or methodology in respect of their allocations. Members who voluntarily subscribe to specific statistical best practices would be expected to present and disseminate their data in line with the best practices to which they subscribe.

SDR allocations are a form of unconditional liquidity. SDR Department participants do not have to meet any specific requirements for the receipt of their proportional share in a general allocation. And following such allocation, they have a right to use their SDRs where they have a balance of payments need to obtain currency from members on the Fund's designation plan, and may also use their SDRs to obtain currency from other participants in transactions by agreement.

Despite the unconditional nature of an SDR allocation, there is nothing in the Articles of Agreement that requires the Fund to design program targets in a manner that ensures the full use of SDR holdings. Rather, a case-specific analysis may be undertaken of the extent to which the design of program targets that assume full use of a member's SDR holdings would or would not be consistent with the optimal implementation of its Fund-supported program (e.g., with optimal reserve levels and/or fiscal targets), given the member's circumstances. The relevant legal provisions in this context are not only those governing the use of SDRs, but also those governing the use of the Fund's GRA resources-which apply by extension to the use of resources in the PRGT. These provisions require the Fund, in the context of a member's use of its resources, to establish conditions that will help the member to resolve its balance of payments problems, while also ensuring adequate safeguards for the temporary use of the Fund's resources (ArticleV, Section $3(a))$. In any case, the design of program targets so as not to assume automatically the full use of allocated SDRs does not constitute conditionality on the SDRs, but rather conditionality on the use of the Fund's resources: the member could use its SDRs and still meet these targets through other means.

While indirect limitations on SDR use may result from GRA/PRGT-supported program targets, direct limitations on SDRs use (e.g., establishment of a performance criterion on SDR use) would be problematic. First, members have a right under the Articles to use their SDRs as summarized above, and a Board UFR decision directly restricting such use would be inconsistent with these provisions. In addition, a condition on use of SDRs per se is unlikely to be reasonably related to the purposes for which UFR conditions are to be established under ArticleV, Section 3(a): ultimately, what matters in helping a member solve its problems and ensuring safeguards for the Fund is not SDR use as such, but the strength of the member's Fund-supported program in broad macroeconomic terms. 
13. While a majority of countries have adopted the BPM6 guidelines, accounting treatments may deviate for countries that have not yet moved to BPM6. ${ }^{15}$ Country teams should encourage the authorities to reflect immediately the acquired SDRs as a result of the allocation in reserve assets and in long-term liabilities in line with BPM6. Following the pre-established procedures, the IMF's Statistics Department (STA) has been using the Finance Department data to revise SDR transactions and positions data in its statistical publications - International Financial Statistics (IFS) and the Balance of Payments Statistical Yearbook (BOPSY) - for those countries who have not yet adopted the BPM6 standards.

\section{GENERAL MACROECONOMIC IMPLICATIONS AND POLICY ADVICE}

14. Member countries can use their SDRs unconditionally. ${ }^{16}$ Members do not have to meet any requirements to receive their share of SDRs in a general allocation and they have the right to use SDRs in transactions (i.e., to exchange their SDRs to obtain freely usable currencies) or in operations authorized by the Fund (including, payments of financial obligations, loans, pledges donations, swaps, and forward transactions) with other SDR Department participants or prescribed holders (see Annex III). ${ }^{17}$ It is expected that SDR transactions will continue to take place via the voluntary SDR trading market. In the rare event the Voluntary Trading Arrangements' (VTA) capacity is not sufficient, or a willing counterparty to a transaction cannot be identified through the VTA or bilaterally with another participant or prescribed holder, then the designation plan would call upon members with sufficiently strong external positions to provide currencies in exchange for SDRs of the member that represents a balance of payment need (see Box 1 in Annex III).

15. It is important to recognize that the allocation is not a transfer of wealth. As mentioned in the previous section, the allocation of SDRs involves an increase in assets (holdings) and a matching increase in long-term liabilities (allocation), so no transfer of wealth occurs.

16. The SDR allocation is likely to increase members' policy space that can be retained or used. Policy space related to the SDR allocation is defined as the incremental ability of the member

\footnotetext{
${ }^{15} \mathrm{~A}$ list of the 177 economies reporting external sector statistics (ESS) on BPM6 basis (of which, 161 are Fund member countries) is available here.

16 "Use" defined narrowly is the drawdown of SDR holdings to obtain freely usable currency (either for spending or to change the composition of reserves), or to conduct authorized operations with participants and prescribed holders in the SDR Department. However, since SDR holdings are part of the pool of a member's reserve assets, it is difficult to identify the specific use of SDRs due to their fungibility-for example, SDR holdings may be maintained but enable the use of other reserve assets to finance a larger balance of payments deficit.

${ }^{17}$ Article XXX ( $f$ ) defines a "freely usable currency" to mean a member's currency that the Fund determines is: (i) widely used to make payments for international transactions, and (ii) widely traded in the principal exchang e markets. As of end-July 2021, the Executive Board has determined that the currencies in the SDR Basket, including the British pound sterling, Chinese renminbi, the euro, the Japanese yen, and the U.S. dollar, are freely usable currencies. The rules for the computation and the historical data for the SDR interest rate are available at: https://www.imf.org/external/np/fin/data/query.aspx.
} 
to undertake discretionary macroeconomic policies that would not have been possible absent the SDR allocation. Members can choose to hold the newly allocated SDRs to boost their reserve buffers. Doing so can help improve members' market access (e.g., by reducing members' borrowing costs), ease external financing constraints, and enhance their resilience. Members may also exchange SDRs for freely usable currencies to adjust the composition of their international reserves, or to ease liquidity constraints and finance additional spending. SDR Department participants with obligations due to the IMF may also decide to use the SDRs to cover those obligations (see Annex III).

\section{A central policy question therefore is whether this policy space should be retained or} used, either partially or entirely. At the current juncture and going forward, staff advice on the decision to retain or use policy space should consider a range of factors, including-given the exceptional circumstances - where each member stands in containing the COVID-19 pandemic, the adequacy of its reserves, the availability of fiscal and monetary policy space, considerations on domestic and external debt sustainability and financial stability, financing constraints, and other country-specific factors. The use of SDRs should also consider the domestic institutional set-up, including the institutional arrangement between the central bank and a government agency. ${ }^{18}$ These considerations are discussed below.

\section{COVID-19-related Policy Guidance}

\section{The most urgent policy priority at the time of the issuance of this Note is to end the} COVID-19 pandemic everywhere. Countries will need to address policy challenges related to the pandemic to prevent extended scarring, including from an increase in poverty, while being mindful of containing external financing needs and managing debt vulnerabilities. They will also need to address the pre-pandemic trends of low productivity growth and rising inequality. The policy space provided by the allocation could be thus used to confront the unprecedented health and economic crisis and accelerate the global recovery.

\section{Countries that need to prioritize the policy response to the COVID-19 crisis should act}

flexibly and swiftly. Reflecting the exceptional nature of the pandemic, consideration could be given to using the policy space provided by the SDR allocation in a timely fashion to limit the fallout from COVID-19 and minimize long-term scarring in a manner consistent with macroeconomic sustainability. ${ }^{19}$ Using resources, including SDRs, to help mitigate the impact of the pandemic can yield considerable benefits in the near and long term that can, in many cases, exceed the costs of using policy space. Staff advice should also acknowledge that a widening of the fiscal deficit to support a faster recovery in the near term may, under certain conditions, improve debt sustainability over the medium-term by preventing scarring that would have otherwise occurred. That said, the

\footnotetext{
${ }^{18}$ In this Guidance Note, the term "government agency" is used to refer to, inter-alia, ministries of finance, treasuries, and other domesticinstitutions that are not considered the member's monetary authorities.

${ }^{19}$ While the COVID-19 crisis is still unfolding, policies should help vulnerable households and viable firms, including with targeted fiscal measures within credible medium -term policy frameworks. In countries with limited fiscal space, spending should be prioritized for healthcare and assistance to the most vulnerable.
} 
potential benefits of using the SDRs for fiscal purposes need to be weighed against risks, which will vary by country.

20. While members should act flexibly to end the crisis, staff should stress the importance of sustainable policies. Members should not use the policy space provided by the allocation to delay a needed debt restructuring, pursue unsustainable macroeconomic policies, or delay needed macroeconomic adjustment and reforms. Staff should also urge the authorities to ensure transparent use of the allocation (see section on transparency).

21. As countries exit the emergency phase of the COVID-19 pandemic, policy advice should shift to supporting a resilient, inclusive, and sustainable recovery. As the recovery takes hold, the Fund's COVID-19 policy advice is focused on how and when to pivot from crisis support to policies that facilitate the necessary resource reallocation and rebuild macroeconomic buffers, ultimately helping to secure a more resilient, inclusive, sustainable, and green recovery.

\section{External Sustainability and Monetary Policy}

22. Where a member country has a precarious reserve position, rebuilding reserve buffers would be critical. As countries exit the COVID-19 pandemic, it is expected that many countries will need to bolster their reserves, in some cases to rebuild them after recent drawdowns, and in other cases to build up an adequate reserve cushion to guard against a potentially higher level of post-pandemic risks and vulnerabilities. Similarly, countries that aim to bring about an adjustment in the exchange rate or introduce greater exchange rate flexibility may require an increased level of reserves. For dollarized or euroized economies (i.e., those that do not have a domestic currency), locking in most SDR holdings would help bolster their scope to exercise lender of last resort functions.

23. Where the level of reserves is not a concern, there will generally be more scope to use the policy space provided by the SDR allocation. This can be done by running down either SDR holdings or other reserve assets. From a reserve management point of view, the choice of which reserves to use would be primarily an asset allocation decision (see section on reserve management). ${ }^{20}$

24. Any use of SDR holdings should be designed to preserve macroeconomic sustainability, including monetary and external sustainability. SDRs can support countercyclical monetary policy and help limit excessive exchange rate adjustment. While SDRs could be used to help alleviate disorderly conditions in the foreign exchange market, staff should emphasize that intervention should not be a substitute for medium-term adjustment and structural reforms.

\footnotetext{
${ }^{20}$ Countries would need to hold or acquire SDRs (e.g., by exchanging other foreign exchange assets) to cover interest payments on SDR allocations. Members should also hold enough SDRs to cover other obligations to the IMF payable in SDRs.
} 


\section{Fiscal Policy}

25. An important question is whether to relax fiscal constraints and pursue countercyclical policies. The SDR allocation may allow for the possibility of a larger fiscal deficit and/or grea ter use of reserves for budgetary financing (where permissible by domestic institutional arrangements), especially where fiscal financing constraints are binding. This can be achieved by increasing net central bank credit where permitted, or by direct conversion of SDRs into other currencies by a government agency. The decision to relax the fiscal stance would depend on individual country circumstances. Any relaxation of fiscal policies should be set in the context of a medium-term framework to ensure that fiscal sustainability and credibility are maintained. The potential use of SDRs should also consider whether policy is responding to shocks that are temporary or permanentwith the latter calling for adjustment rather than financing - and to the need to promote high-quality spending, as well as transparency and good governance. ${ }^{21}$

\section{Country teams should highlight the importance of respecting the existing institutional} framework between the central bank and government agencies and promoting transparency and good governance in their relationship. ${ }^{22}$ They should communicate the importance of sound on-lending practices from the central bank to a government agency by ensuring transparency and good governance in the use of the SDRs for fiscal purposes (see section on transparency). And, as mentioned earlier, country teams should emphasize that the SDR allocation is not a transfer of wealth, but should be considered similarly to a drawdown of an outstanding credit line that, once used, will affect a member's debt sustainability (see section on debt sustainability).

\section{A member's decisions on the on-lending arrangements should be informed by financial} autonomy considerations for central banks. These include: (i) whether the on-lending balances fall into the statutory limits or prohibitions on credit to government; and (ii) the accounting consequences that follow from the terms and conditions of such on-lending based on the central bank's financial reporting framework (such as International Financial Reporting Standards-IFRS). The terms and conditions should normally be documented in an underlying framework agreement and the accounting consequences, including valuation of the underlying claim in the government, discussed with the central bank auditors to determine the impact on the central bank's financial position.

28. Where public debt is assessed to be unsustainable by IMF staff, SDR holdings should not be used to delay a required debt restructuring and any accompanying policy adjustment. Any use of SDR holdings should be consistent with debt sustainability and be implemented in the

\footnotetext{
${ }^{21}$ While the COVID-19 crisis is a temporary shock, countries where it causes permanent scarring may need to undertake adjustment in the medium term where needed to restore fiscal sustainability.

${ }^{22}$ For the purposes of this Note, on-lending is described as the central bank's lending to government agencies the proceeds from the exchange of SDRs for freely usable currency, consistent with domestic legal and institutional frameworks. Central banks may face restrictions (or may altogether be prohibited) to lend to the government in perpetuity, in a currency other than the local one, or at interest rates comparable to the SDR rate. Staff advice should thus strongly emphasize the importance of ensuring that any fiscal use of the SDR allocation be consistent with domestic institutional frameworks and procedures.
} 
context of a well-defined and announced medium-term fiscal plan. In the context of a restructuring to address unsustainable debt or a financing gap, it is highly recommended that the use of SDR holdings should not undermine fair burden sharing among creditors (e.g., using SDRs to settle any claims before they are treated), as this could complicate the subsequent restructuring process.

29. SDR holdings can be used to reduce expensive public debt or arrears. In cases where SDRs are used to help reduce external debt, the country's NFA position would remain unchanged. The authorities could also consider using their SDRs to reduce expensive domestic public debt or domestic arrears. In both cases, the decision should be taken within the framework of an overall debt management strategy and respecting domestic institutional arrangements.

\section{Additional Considerations}

\section{The net cost of using SDRs will depend on the overall impact on the macroeconomic} framework.

- The direct cost of exchanging SDRs for freely usable currencies is proportional to the member's shortfall in SDR holdings relative to its cumulative allocation. Members earn interest on their SDR holdings and pay charges on their cumulative allocation at the same SDR interest rate. If a member's holdings are equal to its allocation, there is no net interest receipt or payment to the SDR Department. Participants that use their SDRs will pay more charges than they will receive interest on their holdings to the extent that they hold fewer SDRs than their cumulative allocations. Conversely, participants that hold more SDRs than their cumulative allocations will receive more interest on their holdings than the charges they will pay on their allocations.

- The direct cost of exchanging SDRs for freely usable currencies may be compensated by the return on their use. The net interest charge may be offset by the interest earned on the alternative use of these SDRs (e.g., investment returns on potentially higher yield assets obtained with proceeds from the sale of SDRs or savings from paying off debt at higher interest rates); or by the improvement in public finances from a stronger macroeconomic performance if the SDRs are used to finance high-quality fiscal programs. ${ }^{23}$

31. Authorities should also consider the risks-albeit low-associated with the possibility of a reconstitution requirement or a cancellation of SDRs. Under a "reconstitution requirement," participants in the SDR Department could be asked to maintain an average holding of SDRs at not less than a specified percentage of its average net cumulative allocation over a specified period (see Annex II). If a reconstitution requirement is reintroduced, it would eventually require the member with holdings below the specified percentage of its cumulative allocation to reconstitute its holdings by acquiring an amount of SDRs sufficient to increase its holdings to the required minimum. Moreover, the Board of Governors also has the prerogative to cancel existing SDRs based on its assessment of an absence of long-term global reserve needs. In such a scenario, the Fund's Articles

\footnotetext{
${ }^{23}$ This improvement could reflect, for example, a faster recovery and thus faster rebound in tax revenues and unwinding of crisis-related expenditures.
} 
of Agreement mandate that SDR Department participants will have to provide freely usable currencies to cover the difference between their SDR holdings and the amount being cancelled if the difference is negative. While the reconstitution requirement was abrogated in 1981 (see Annex II), and SDRs have never been cancelled, the possibility of a reconstitution or cancellation cannot be ruled out. Country teams should explain to country authorities that according to Article XIX Section $6(b)$, the rules for reconstitution may be reviewed at any time. For these reasons, open SDR positions carry a rollover risk.

32. Use of SDRs, particularly in low-income countries, warrants specific considerations. Due regard should be given to debt sustainability concerns particularly in LICs given that use of SDR holdings is effectively charged at the variable non-concessional SDR interest rate. Though currently at historical lows, the SDR interest rate has averaged about 3.8 percent since its inception and its cost could exceed other sources of financing available to LICs, including concessional financing (see Figure 1). ${ }^{24,25}$ Consideration should also be given to any capacity constraints facing LICS regarding formulating and implementing macroeconomic policies and reforms, among other constraints, as well as their financing conditions, with generally more scope to access concessional financing and less scope to tap capital markets than emerging market economies.

Figure 1. Selected Interest Rates (In percent)

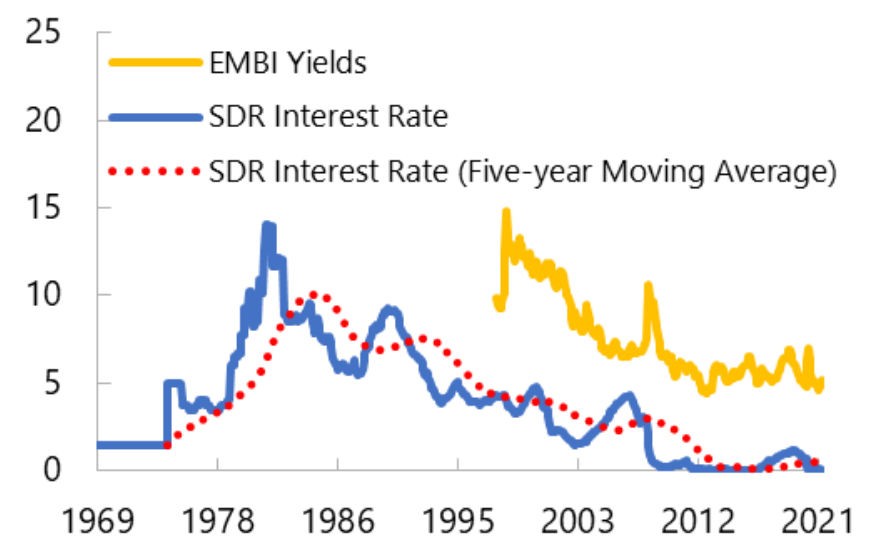

Source: International Monetary Fund. Fund staff calculations.

\section{Implications for Staff Reports}

\section{Staff reports should clearly describe the implications of the SDR allocation. ${ }^{26}$ They}

should indicate in the main text that, in the first instance, the allocation supplements existing reserve assets. In cases where SDR holdings have been used, staff reports should mention in broad terms to what extent the allocation may have helped loosen fiscal financing constraints and implement countercyclical macroeconomic policies-including for priority spending to fight the COVID-19 pandemic; reduce debt; support reserve management operations; and/or provide liquidity to the private sector. In these cases, staff reports should highlight the extent to which the use of SDRs was

\footnotetext{
${ }^{24}$ In this context, the allocation may be compared with an open-ended line of credit at the floating SDR interest rate.

${ }^{25}$ SDR allocations do not fall within the definition of "debt" under the Fund's Guidelines of Performance Criteria with Respect to External Debt in Fund Arrangements. Therefore, they are not subject to the external debt limits established pursuant to those Guidelines (see paragraph 70).

26 The Fund has committed to prepare an ex-post report two years after the 2021 general allocation of SDRs. This report will be based on Article IV consultation discussions, highlighting the importance for regular country teams' follow up.
} 
consistent with Fund advice, including in relation to transparency and accountability. Regarding the use of SDRs in the context of the COVID-19 crisis, staff reports can, where relevant, include a succinct discussion of the impact of using SDRs both in the near-and the medium-term.

\section{IMPLICATIONS FOR DEBT SUSTAINABILITY ANALYSES}

\section{This section provides guidance on how the SDR allocation enters DSAs, and it updates the 2018 LIC-DSF. ${ }^{27}$}

35. The SDR allocation, by itself, is not expected to weaken a member's debt sustainability and could even enhance it. The SDR allocation provides liquid assets to the member (SDR holdings), with no repayment obligations absent cancellation or reconstitution of SDRs. A new SDR allocation does not generate, by itself, net interest payments, and the net worth of the country is unaffected at the time of the allocation. A member's debt sustainability can benefit from the SDR allocation even if it does not exchange its holdings for freely usable currency or use the policy space provided by the SDR allocation. For instance, SDR allocations normally lead to an increase in NIR and can contribute to lowering sovereign financing risks. Enhanced resilience can also boost potential growth and help improve debt dynamics.

\section{A member's policy choices made in response to SDR allocations can affect debt} sustainability. The impact on debt sustainability will depend on how SDRs are used and the effects on the member's macroeconomic framework. In assessing this impact, country teams must consider that when SDR holdings fall below a member's cumulative allocations, net interest payment obligations to the SDR Department are generated. ${ }^{28}$ So, for example, if SDRs are used to finance an increase in the fiscal deficit (by exchanging SDRs for freely usable currency and using those proceeds to finance the budget), then this use would impact debt sustainability through the higher net interest obligation to the SDR Department. If, instead, the country uses SDRs to retire debt, then the impact on net interest payments will depend on the interest rate on retired debt compared to the SDR interest rate. A similar issue arises when a country exchanges a portion of its SDR holdings into foreign exchange and retains these as foreign reserves, as is the case in reserve management operations. ${ }^{29}$

\footnotetext{
${ }^{27}$ Note that the term "DSF" refers to the tools used to conduct debt sustainability analyses.

${ }^{28}$ As explained earlier, a member would receive net interest payment if its SDR holdings exceed its cumulative SDR allocation and make net interest payments if its cumulative SDR allocation exceeds its SDR holdings.

${ }^{29}$ A fuller analysis would need to allow for differences in currency composition and inflation.
} 


\section{Implications for the External DSA ${ }^{30}$}

\section{The following approach to incorporating SDRs in the External DSA should be applied:}

- The way in which SDRs are accounted for in the external DSA is independent of whether the SDR position is recorded on a government agency or the central bank balance sheet. In both cases, the shortfall of holdings with respect to cumulative allocations of SDRs contribute to external debt and external interest payments in the same way in the External DSA, because the external debt sustainability is a function of the external debt of the country as a whole.

- Only the positive difference between the SDR cumulative allocation and SDR holdings is included as part of the external debt in the External DSA. If holdings exceed cumulative allocations, the contribution to gross external debt is zero.

- Only the net positive external interest payments on SDRs (i.e. the difference between interest due on the cumulative SDR allocation and the interest earnings on the SDR holdings) are included as part of total external interest payments. ${ }^{31}$

38. Some adjustments to the data based on BPM6 would be required before these are used to populate the external DSA template. Under BPM6, the full SDR allocation is included as part of the gross external debt, and the full interest due on the SDR allocation is included under gross external interest payments. Hence, BPM6 statistics for gross external debt and gross external interest payments will need to be adjusted before they are incorporated in the external DSA: SDR holdings need to be subtracted from gross external debt and interest earned on SDR holdings needs to be subtracted from gross external interest payments.

\section{Incorporating SDR Allocations in Public DSAs}

\section{The way in which SDRs are accounted for in DSAs depends on both the member's institutional setup and whether the country uses the LIC-DSF or MAC-DSA:}

\section{- In most countries, SDRs are recorded on the central bank's balance sheet, which is usually} outside the DSA perimeter. ${ }^{32,33}$ In this case, regardless of whether the member is paying

\footnotetext{
${ }^{30}$ The External DSA is only required for MACs. At the time of preparing this note, the External DSA is not generally required in Article IV staff reports but is required for MAC's IMF-supported program documents.

31 If holdings exceed cumulative allocations, the contribution to net external interest payments is zero.

32 The central bank is generally excluded from the DSA perimeter. In cases where a central bank recapitalization is needed, however, the DSA perimeter would extend to the central bank debt, including SDR allocations in excess of holdings. In the MAC DSA, the central bank is generally outside of the DSA perimeter, except in cases of central banks with large negative capital positions and/or where the country team considers the central bank to be involved in significant direct monetary financing of the budget and/or quasi-fiscal activities. In the LIC-DSF, central bank debt issuance or foreign exchange swaps for the purposes of monetary policy or reserves management are excluded from the DSA perimeter. At the same time, known and anticipated recognition of conting ent liabilities constitute part of the public sector debt in the LIC-DSF.

${ }^{33}$ The procedure described in the following bullet applies when the central bank is part of the DSA perimeter.
} 
interest on shortfalls of SDR holdings relative to its cumulative allocation, there is no direct SDRrelated input to the DSA. ${ }^{34}$ If these resources are on-lent to a government agency within the DSA perimeter, then they would be reflected in the DSA as this lending would be registered in the GFS debt statistics already (which are a direct input in the DSA), as would the debt service by a government agency to the central bank. But if the SDR holdings are used for a reserve management operation of the central bank, then these resources do not go to a government agency and do not impact the debt sustainability of the government (at least not directly). The central bank may exchange SDR holdings for other financial assets, in which case the impact on the central bank balance sheet would depend on whether interest lost on holdings exchanged is greater than the interest earned on other assets. Just like any other central bank operation, this action does not enter directly into the DSA except for what is already captured in GFS debt and debt service statistics. ${ }^{35}$

- If SDRs are recorded on the balance sheet of a government agency (i.e., are part of the DSA perimeter), then the SDR holdings would be added to other readily available financing sources that can mitigate financing risks in the DSA. ${ }^{36}$ The impact of the allocation will impact both debt and debt service indicators depending on whether the member has a negative or positive differential of its SDR holdings relative to its cumulative SDR allocation (i.e., the sign of its "net SDR position"):

- If the net SDR position is negative, the shortfall in SDR holdings relative to allocations must be included in the stock of nominal debt in both the LIC-DSF and the MAC-DSA, and the net SDR interest obligation must be reflected in future interest expenditures of the government. In the LIC-DSF, the present value of the net SDR interest expenditures is incorporated as part of the present value of debt.

- If the net SDR position is positive, then the net interest income generated from SDR holdings in excess of a member's cumulative allocation is assessed on a gross basis. The net interest income is not deducted from debt service obligations nor from the stock of debt. The net SDR interest revenue would, however, be included in the member's fiscal balance.

\footnotetext{
${ }^{34}$ There could still be an indirect impact. Specifically, use of an SDR allocation could impact DSAs to the extent that the central bank mobilizes SDR resources to lend to a government agency, including if its operations facilitate higher lending by domestic banks to the government. The impact on debt sustainability would be captured in the government's debt service (which would include any interest and amortization of central bank loans or loans from domestic banks facilitated by the related central bank operations), and the government's stock of debt (nominal and in present value). Such operations could also affect the central bank net income and, depending on country-specific arrangements, could alter the profit transfers to the government, which would impact the government's primary balance, potentially mitigating the impact of higher interest payments.

${ }^{35}$ Nevertheless, see paragraph 9 and Box 2 on understanding the rights and obligations relevant to a member and the SDR Department.

${ }^{36}$ In the rare event that the SDRs are recorded in a government agency outside of the DSA perimeter and different from the central bank, SDR drawdowns by this agency should still be included in the DSA.
} 
The implications for the use of SDRs for the Public DSA based on domestic institutional arrangements and potential uses is summarized in Table $1 .{ }^{37}$

\begin{tabular}{|c|c|c|}
\hline \multirow[b]{3}{*}{ Use $^{1}$} & ble 1. Uses of SDR Holdings_-Im & tions for the Public DSA \\
\hline & \multicolumn{2}{|c|}{ SDRs recorded at } \\
\hline & Central Bank (CB) & Government Agency (GA) \\
\hline \multirow[t]{3}{*}{$\begin{array}{l}\text { Budget } \\
\text { support }\end{array}$} & $\begin{array}{l}\text { - CB is outside of DSA perimeter } \\
\text { - GA borrows from CB (i.e., on- } \\
\text { lending) } \rightarrow \text { adds to domestic public } \\
\text { debt and debt service }\end{array}$ & $\begin{array}{l}\text { - Negative net SDR position adds to public } \\
\text { debt and debt service }{ }^{3}\end{array}$ \\
\hline & $\begin{array}{l}\text { For DSA, increase in domestic public } \\
\text { debt and domestic debt service } 2\end{array}$ & $\begin{array}{l}\text { For DSA, increase in external public debt and } \\
\text { external debt service } 2\end{array}$ \\
\hline & $\begin{array}{l}\text { - CB is outside of DSA perimeter } \\
\text { - GA borrows from CB to retire other } \\
\text { debt }\end{array}$ & - GA uses SDR holdings to retire debt $^{2}$ \\
\hline \multirow{2}{*}{$\begin{array}{l}\text { Retire public } \\
\text { debt }\end{array}$} & $\begin{array}{l}\text { Net effect on DSA depends on terms of } \\
\text { respective debts (but no net impact on } \\
\text { nominal debt level) }\end{array}$ & $\begin{array}{l}\text { Net effect on DSA depends on terms of } \\
\text { respective debts (but no net impact on } \\
\text { nominal debt level) }\end{array}$ \\
\hline & $\begin{array}{l}\text { - CB is outside of DSA perimeter } \\
\text { - CB owes interest to SDR }\end{array}$ & $\begin{array}{l}\text { - GA uses SDR holdings to purchase other } \\
\text { assets }\end{array}$ \\
\hline $\begin{array}{l}\text { Reserve } \\
\text { management }\end{array}$ & $\begin{array}{l}\text { Department, but receives interest on } \\
\text { acquired reserve assets }\end{array}$ & $\begin{array}{l}\text { - Net negative SDR position adds to public } \\
\text { debt (and debt service) }{ }^{2}\end{array}$ \\
\hline $\begin{array}{l}\text { (exchange of } \\
\text { SDRs for } \\
\text { freely usable }\end{array}$ & $\begin{array}{l}\text { Net effect on DSA depends on } \\
\text { difference b/w SDR rate and rate on } \\
\text { reserve assets - accounted for through }\end{array}$ & $\begin{array}{l}\text { For DSA, increase in total public debt (and } \\
\text { debt service) in the amount by which SDR } \\
\text { holdings (and related interest revenues) }\end{array}$ \\
\hline currencies) & $\begin{array}{l}\text { CB profit transfers to the government } \\
\text { agency; no direct impact on debtor } \\
\text { debt service metrics in the DSA. }\end{array}$ & $\begin{array}{l}\text { decrease. Difference b/w SDR rate and rate } \\
\text { on other reserve assets is accounted for } \\
\text { through fiscal balance. }\end{array}$ \\
\hline
\end{tabular}

\section{In the LIC-DSF, concessionality in SDR-related central bank loans to the government should be taken into account when significant. Central bank loans to the government are typically}

\footnotetext{
${ }^{37}$ Although the negative net SDR position is added to the stock of nominal debt in the DSA, the associated increase in the stock of debt, interest payments, and present value of debt will not, by rule, be allowed to prompt a worse debt sustainability classification. In any case, this accounting is not expected to be a determining factor in debt sustainability assessments. In the LIC-DSF when the SDR is recorded on the Treasury's balance sheet, only the interest payments and their present value impact the debt sustainability assessment. When recorded on the central bank balance sheet, only the domestic (not the external) stock of debt and domestic debt service would be impacted by central bank loans motivated or backed by an SDR allocation at the central bank. Hence, the impact on the assessment of the risk of external debt distress in the LIC DSF (the primary DSF output) would be very limited when SDRs are recorded and used by the Treasury and null when on-lent by the central bank. In the MAC-DSA and especially in the new Sovereign Risk and Debt Sustainability Framework for Market-Access Countries, the stock of debt has a limited impact on the assessment, as other factors like the dynamics of the debt stock and the financing risks are given more weight. Nonetheless, staff should examine the impact of this debt component on the debt sustainability assessments and avoid situations where an increase in debt owing to a net negative SDR position (or a portion of central bank lending equivalent to that position in cases where SDRs are recorded a the central bank), tips the balance on its own to a worse risk of debt distress classification or to a worse debt sustainability classification of the country, unless clearly justified.
} 
domestic debt, and the LIC-DSF template generally assumes that public domestic debt is issued at market rates and therefore its present value is equal to its nominal value. There may be cases where central banks seek to mirror the terms of the SDR allocation in a loan to the government. Given the favorable terms of using SDRs vis-à-vis market rates at the time of the 2021 SDR allocation (see Figure 1), such loans would typically be concessional. ${ }^{38}$ In certain country cases where there is a material impact for the debt sustainability assessment, the present value of SDR-related central bank loans could instead be calculated by discounting the corresponding debt service flows using the same discount rate as for external debt. Such SDR-related lending would need to meet the following conditions: (i) be clearly identifiable as lending related to or facilitated by the SDR allocation; (ii) be disbursed to the budget within 12 months after SDRs are allocated and recorded in the central bank; (iii) be smaller or equal than the size of the SDR allocation; and (iv) contain a grant element of at least 35 percent and be sizable enough to have a material impact on the DSA.

\section{The treatment of SDR-related lending to LIC-DSF countries in currency unions would} follow the existing classification of regional central bank loans. Central bank loans to member governments, motivated or backed by SDRs, would be classified as external or domestic borrowing according to the practices used in the past for other regional central bank loans in each country. Among countries in a currency union that use the LIC-DSF, the most common practice is to classify regional central bank loans to member governments as domestic debt. This classification would result in the same impacts from an SDR allocation and related SDR lending as in the case of a country where the SDR position is recorded at its own central bank. ${ }^{39}$

42. Cases where treatment of SDRs in the DSA differs from that in GFS are limited to cases where SDRs are recorded on the balance sheet of a government agency. ${ }^{40}$ If the SDRs are recorded at a government agency, then adjustments to GFS statistics would be needed to: (i) include the net SDR position as part of the stock of external debt instead of the full SDR allocation; and (ii) include the net interest payments on the net SDR position in the external interest payments rather than the gross interest expenditure on the full allocation.

\section{If the SDR position is recorded at the central bank, the allocation carries no adjustments to the data from the government's statistics from GFS before being incorporated} into the DSAs. There are two reasons why the GFS is not adjusted: (i) if SDR holdings are saved and not used, SDRs do not appear in the government accounts and fiscal tables; (ii) if SDRs are used for central bank on-lending to a government agency, then GFS would record the loan of the central

\footnotetext{
${ }^{38}$ A concessional loan has a grant element of at least 35 percent when applying the 5 percent discount rate. The SDR terms are currently highly concessional based on prospects for SDR interest rates implied by market pricing.

${ }^{39}$ For economies in centralized currency unions, BPM6 recommends treating these loans as domestic transactions/positions. This practice is appropriate because the monetary authority functions for member countries in these currency unions are deemed to be carried out by a national (resident) agency. Typically, the regional central bank of a centralized currency union maintains national offices in each member economy. This institutional unit, called "the national agency," acts as the central bank for that economy and must be treated for statistical purposes as an institutional unit that is separate from the headquarters of the regional central bank.

${ }^{40}$ Data from GFS is the basis for fiscal tables and the DSAs for many countries. For this reason, it is important to minimize the adjustments to GFS that are needed before this data is entered in the DSAs.
} 
bank in government debt statistics (nominal terms), and the debt sustainability analysis would include this loan as part of government nominal debt (see Table 1 and Box 2).

\section{In sum, the updated guidance departs from prior staff guidance related to debt} sustainability analyses by proposing to: (i) treat the negative net SDR position (i.e., the difference between a member's SDR holdings and its cumulative allocation) as part of the stock of nominal debt in the public DSA in both the LIC-DSF and the MAC-DSA when recorded on the balance sheet of a government agency; (ii) include the net SDR position in the stock of external debt in the External MAC-DSA independently of where the allocation is recorded; and (iii) not directly include in the public DSA (LIC-DSF and MAC DSA) the use of SDRs that are recorded in the central bank balance sheet, as public debt that is SDR-related will be already captured in the GFS.

\section{Box 2. Modifications to Past Guidance for DSAs}

This new guidance incorporating the SDR allocation into DSAs differs from previous editions (e.g., 2013 and 2018 LIC-DSF guidance and 2009 SDR guidance). The new guidance aims to reflect better the impact of SDRs on debt sustainability, depending on their use, and attaining a close-to-neutral treatment of SDRs across different institutional arrangements.

The SDR allocation net of holdings should be part of the stock of nominal debt in the public DSA (whether LIC-DSF or MAC-DSA), when recorded in a government agency's balance sheet, and in the External MAC-DSA, independently of where it is recorded. The 2009 guidance excluded a country's liabilities to the SDR Department (whether in excess of holdings or not) from the nominal stock of gross external debt in debt sustainability analyses because members are under no obligation to reconstitute their SDR holdings. However, this approach diverges from the treatment of other long-term liabilities, including perpetuities, which are included in debt. Moreover, it results in significantly different treatment of SDRs in public debt sustainability analyses when these are: (i) recorded on the government balance sheet and used to finance the deficit, where they would not be included in the government debt, versus (ii) when these are recorded in the central bank balance sheet and then followed by a loan from the central bank to the government to finance the deficit, which would lead to an increase in government debt.

The net SDR position recorded on the central bank balance sheet should not be included as direct input in the public DSA in the LIC-DSF. The 2018 LIC-DSF guidance states that "the DSA should estimate the impact of the SDR allocation on debt sustainability by capturing the net interest payments that arise when SDR holdings fall below a member's SDR allocation." This could be understood as implying that the LIC-DSF should include the net interest payments on SDRs even when SDRs are recorded in the central bank accounts and the central bank is not part of the DSA perimeter. This can lead to problems of double counting of net interest payments, overstating the impact of reserve management operations on debt sustainability, and requiring extensive adjustment of GFS data. Instead, in this case, the use of SDRs should only enter the DSA to the extent that it affects the transfer of profits from the central bank to the government or to the extent (and on the terms) that resources are then lent to the government. 


\section{PROMOTING TRANSPARENCY AND ACCOUNTABILITY IN THE USE AND THE REPORTING OF SDRs}

\section{Transparency in the use of SDRs}

45. The Fund promotes public sector transparency and accountability across the IMF's membership. Most notably, the 2018 Framework for Enhanced Fund Engagement on Governance establishes a centralized process for assessing governance weaknesses and related reform priorities in each member country where these are significant. ${ }^{41}$ Continued application of this Framework in surveillance, program support, and capacity development activities can help foster improvements in public-sector transparency and accountability across the Fund's membership, including in the use of SDRs. This section discusses several elements of the Fund's work on transparency that are relevant for the use of SDRs.

\section{Safeguards Assessment Policy ${ }^{42}$}

\section{The IMF's SAP emphasizes good governance practices that can help promote central} bank transparency in the use of SDRs. Safeguards Assessments are a diagnostic review of a central bank's governance and control framework. The assessments are an integral part of the IMF's lending activities and provide an avenue through which staff make in-depth diagnoses and recommendations aimed at enhancing transparency and accountability in the governance and operations of a member country's central bank. The safeguards framework covers five key pillars to help safeguard IMF disbursements and minimize the risk of inaccurate reporting of key data to the IMF. These pillars include, among others, financial reporting practices and external audit arrangements of the central bank, with international standards as the benchmarks that help assure transparency and consistency in reporting of transactions. ${ }^{43}$

\section{Staff can draw on the SAP to promote transparency in central bank governance and} operations, including in the use of SDRs, where SDRs are held by central banks. In countries in which Safeguards Assessments have been completed, staff should follow-up on the assessment's recommendations in the context of surveillance, program support, and capacity development. In other countries, staff can use the SAP's principles and good practices to inform its recommendations to strengthen central bank governance and operations.

\footnotetext{
${ }^{41}$ See the IMF's external webpage on governance and anti-corruption issues and Progress in Implementing the Framework for Enhanced Fund Engagement on Governance (IMF, 2020) for further information on how this framework is being implemented.

42 Note that the SAP applies to members borrowing from the Fund. This section only applies to instances where the SDR allocations are held by a member's central bank.

43 The benchmarks for financial reporting and external audits are IFRS and International Standards on Auditing, respectively. Other areas are the legal structure, the internal audit mechanism, and the control framework. Governance is an overarching theme across the pillars.
} 


\section{The following good practices may be especially relevant for SDRs:}

- Transparency in the treatment of SDRs in the central bank's balance sheet. Depending on the significance of the SDR holdings, they may be reported directly as an asset line item on the face of the balance sheet in the financial statements or as a disaggregated item in the accompanying disclosure notes. ${ }^{44}$ The SAP requires that central banks be subject to a high-quality independent audit and that the audited financial statements are published, which helps assure the accuracy of reported amounts. Review of the monetary data as part of the assessment also helps assure that such audited amounts are properly reported in the member's NIR.

- Transparency in on-lending SDRs to government agencies. While IFRS-compliant financial statements require disclosure of all material related-party transactions, such as those between the central bank and the government, it is unlikely that there would be detailed reporting in this area unless the transactions were of a particularly significant magnitude. The Fund nevertheless encourages that central banks disclose their members' full position with the IMF (including the SDR balances) in the notes to the financial statements even if such positions are not fully reflected in the balance sheet of the central bank. Consistent with the SAP requirement for an appropriate framework to be in place between the central bank and the fiscal authorities for instances that involve use of IMF resources for budget financing, staff could recommend similar frameworks in cases of on-lending of SDRs. Such frameworks, usually in the form of a memorandum of understanding, could help assure that the responsibilities for timely servicing of the member's financial obligations to the SDR Department are in place in cases where the allocation is recorded at the central bank but the SDRs are used by the member's fiscal authorities (see section on debt sustainability). ${ }^{45}$ In countries with recent Fiscal Safeguards Reviews, ${ }^{46}$ staff should follow up on its relevant recommendations.

\section{Fiscal Transparency}

\section{The IMF's Fiscal Transparency Code (FTC) can help enhance transparency and accountability in the use of SDRs in public finances.}

- The FTC is the international standard for disclosing information about public finances and provides the basis for Fiscal Transparency Evaluations (FTEs). FTEs are voluntary exercises conducted upon request by an IMF member and are the IMF's principal fiscal transparency diagnostic tool. In countries with recent FTEs, staff should follow up on its recommendations in

\footnotetext{
44 More generally, the SDR holdings are recorded as part of foreign reserve assets and the co rresponding allocation as a long-term liability. See section on statistical and accounting treatment.

${ }^{45}$ For an example of a memorandum of understanding on similar matters (e.g., on-lending related to Fund disbursements), see existing guidance on accounting for budget support in Fund programs.

${ }^{46}$ Fiscal Safeguards Reviews apply to cases where a member requests exceptional access to Fund resources and there is an expectation that a substantial portion of the resources will be directed toward budget financing.
} 
their surveillance and program-related work. In other countries, staff can use the FTC to inform their recommendations on strengthening fiscal transparency and accountability.

- The FTC requires that all public assets (which include SDR holdings) and liabilities (which include SDR allocations) be reported in the financial statements to provide a comprehensive picture of the overall financial position of the public sector and its subsectors.

Fiscal transparency will also be strengthened by strong governance and anti-corruption (GAC) and AML/CFT frameworks that are assessed in the context of the Fund's surveillance work and in the context of use of Fund resources.

\section{Transparency in SDR Reporting by the Fund}

50. The Fund already publishes quarterly SDR holdings by member (see Table 2).

Information on participants' SDR allocations and holdings is made available in the Fund's annual and quarterly financial reports. These published reports also include aggregated information on changes in SDR holdings by transaction type. Separately, the IMF Finances webpages, publishes monthly information on SDR allocations and holdings of participants. ${ }^{47}$ The periodic IMF Financial Operations publication also provides extensive information on the functioning of the voluntary SDR trading market and includes details on the operating modalities, capacity, trading by region, and aggregate transaction volumes. ${ }^{48}$

\begin{tabular}{|c|c|c|c|c|c|}
\hline Publicly Available Sources & $\begin{array}{l}\text { Summary } \\
\text { Data of } \\
\text { Receipt and } \\
\text { Use of } \\
\text { SDRs }\end{array}$ & $\begin{array}{l}\text { Holdings } \\
\text { and } \\
\text { Allocations } \\
\text { by Member }\end{array}$ & $\begin{array}{c}\text { VTA } \\
\text { Trading } \\
\text { Market } \\
\text { Modalities } \\
\text { and } \\
\text { Capacity }\end{array}$ & $\begin{array}{c}\text { VTA } \\
\text { Members } \\
\text { and } \\
\text { Summary } \\
\text { Trading by } \\
\text { Region }\end{array}$ & $\begin{array}{c}\text { SDR } \\
\text { Aggregate } \\
\text { Transaction } \\
\text { Volumes } \\
\text { and Trends }\end{array}$ \\
\hline - Annual Financial Statements & $\checkmark$ & $\checkmark$ & & & \\
\hline - Quarterly Financial Report & $\checkmark$ & $\checkmark$ & & & \\
\hline - IMF Finances Webpages ${ }^{1}$ & & $\checkmark$ & & & \\
\hline - IMF Finances iPad App ${ }^{1}$ & $\checkmark$ & $\checkmark$ & & & \\
\hline $\begin{array}{l}\text { - IMF Financial Operations } \\
\text { Publication }\end{array}$ & $\checkmark$ & & $\checkmark$ & $\checkmark$ & $\checkmark$ \\
\hline
\end{tabular}

51. To further enhance transparency, staff will include from now on changes in those holdings by two broad categories (i.e., Fund-related operations and SDR trades). This new reporting aims to strike a balance between providing additional information about SDR use and

\footnotetext{
${ }^{47}$ Data are available at: https://www.imf.org/en/data/imf-finances.

${ }^{48}$ See IMF (2018b).
} 
preserving the nature of the SDR as an unconditional reserve asset (see Table 3 for an example template of this quarterly reporting). Fund related operations include: SDR Department, General Resources Account (GRA), and Poverty Reduction and Growth Trust (PRGT) and other Trust operations, while SDR trades relate to non-Fund transactions (e.g., acquisition and sales of SDRs through the VTA market or through bilateral arrangements, or prescribed operations such as settlement of financial obligations). Particularly, Box 1 and Figure 1 in Annex III, provide further details on the transaction types included within Fund-related operations.

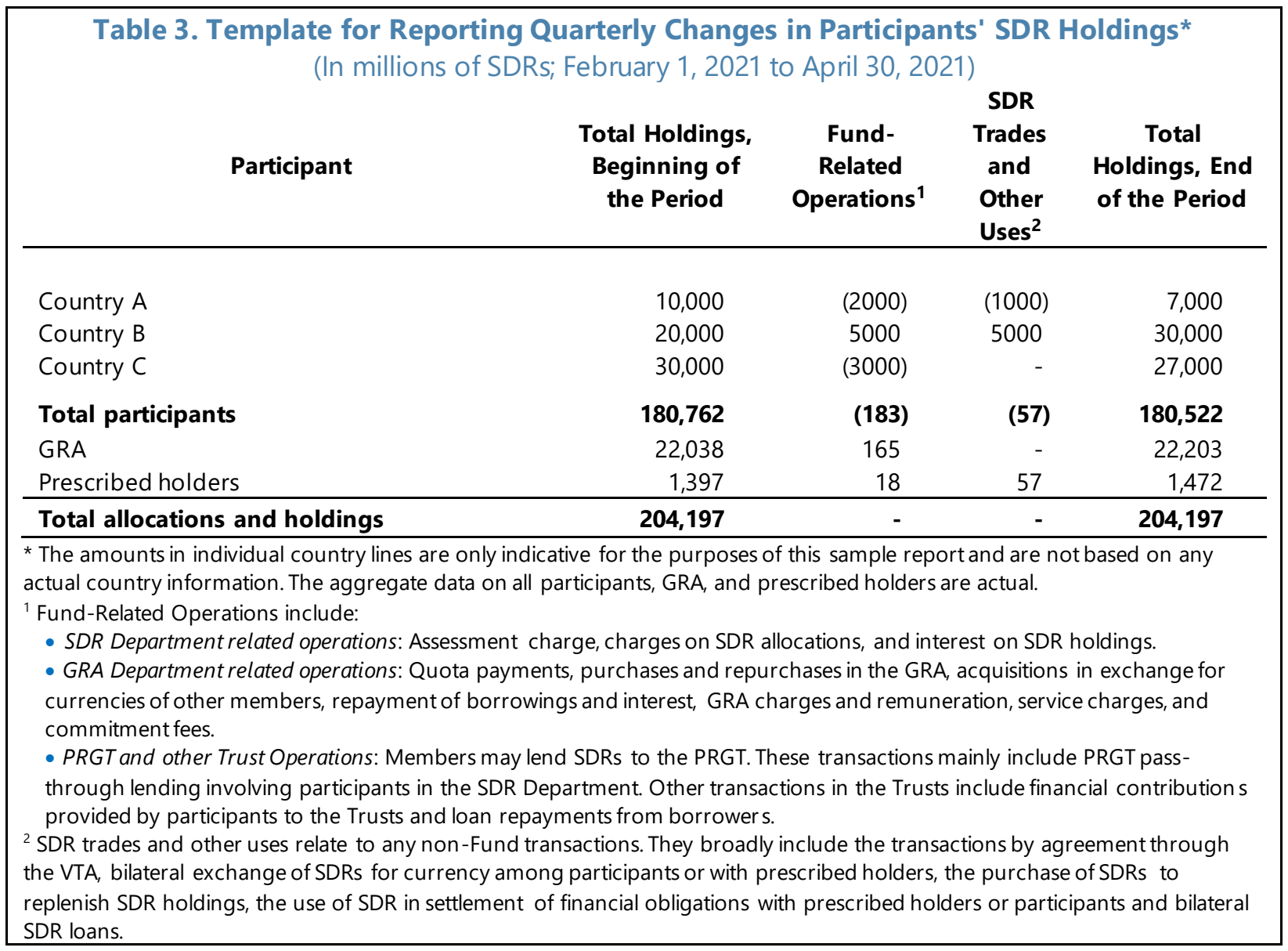

52. The Fund will further enhance transparency by publishing the Board paper, Annual Update on SDR Trading Operations. The paper will provide additional analysis on the use of VTAs and trends in SDR exchanges, including experience with sales after the new SDR allocation and aggregate VTA trading information such as trading ranges.

\section{Staff will also prepare an ex-post report on the use of SDRs two years after the} allocation. The report will review the allocation against the broad macroeconomic context and policy priorities following the COVID-19 pandemic. It will discuss broad patterns of holdings and exchange of SDRs into freely usable currencies; the use of SDRs for transactions with the Fund or expost voluntary channeling; a broad characterization of public spending and macroeconomic trends 
(e.g., reserve buffers, inflation, and growth) following the allocation. The report will also examine the potential effects of the allocation on the stability and resilience of global financial markets.

\section{IMPLICATIONS FOR CENTRAL BANKS' RESERVE MANAGEMENT}

\section{Current central bank practices in managing SDR holdings and allocations vary across member countries. ${ }^{49}$ While some countries manage SDR holdings as part of their reserves (e.g., managing SDR currency exposure through underlying currencies), several others do not take SDR holdings into account in day-to-day reserves management. When it comes to managing risk exposures arising from SDRs, some manage the SDR holdings on a "gross basis" (i.e., not taking the SDR allocation into account), whereas others manage the holdings on a "net basis" (i.e., taking a whole balance sheet view and recognizing that the allocation is an SDR-denominated liability which offsets risk exposures of the SDR holding).}

55. Like other reserve assets, SDR holdings expose central banks to certain financial risks, which need to be understood, measured, and appropriately managed. Most of the risks only arise on a "net basis," so the management of them should also be done on that basis, i.e., taking into account both the member's SDR holdings and its allocation. For the most part, the risks are similar to those of other reserve assets, but SDR holdings also have some unique features. The most important risks--liquidity, currency, interest rate, and credit risks - are discussed below.

\section{Liquidity Risk}

56. The liquidity risk in SDR holdings is minimal. SDRs are equivalent to liquid balances in convertible currencies in nearly every respect. ${ }^{50}$ Over the past three decades, SDRs have been traded through VTAs (see Annexes I and III). From this perspective, SDRs are slightly exposed to some liquidity risk. If voluntary trading cannot be secured in a case where a member declares a balance of payments need, the Articles of Agreement provide for a designation mechanism so that members that need to use SDRs can exchange them for freely usable currencies (see Box 1 in Annex III).

\section{Foreign Currency Risk}

57. The new SDR allocation per se does not change the foreign currency risk of foreign reserves as it comes with an equivalent holding. This follows from the basic asset and liability

\footnotetext{
${ }^{49}$ As elaborated in the section on statistical and accounting treatment, the SDR allocation and holdings are accounted for in the central bank's balance sheet in most member countries. The discussion in this section focuses on the SDR holdings that are managed in the central bank's balance sheet.

${ }^{50}$ Refer to BPM6, paragraph 6.84 on the treatment of SDR holdings and liquidity assumptions in the classification of reserve assets.
} 
management principle that when assets' exposures (holdings) are exactly matched with liabilities' (allocation) exposures, the net exposure is zero.

\section{Foreign currency exposure of a net SDR holding is typically smaller than for an} individual currency owing to the diversification benefits of the SDR basket of currencies. Nevertheless, a net SDR position is subject to currency risk given that the value of the SDR is based on the market exchange rates of the five currencies included in the SDR basket.

59. Hedging activities should be limited to the net open position. Reserve managers typically manage currency risk by maintaining the currency composition of reserves close to their strategic currency benchmark. If SDR holdings are treated on a gross basis, the new allocation is likely to lead reserve managers to adjust their positions, ${ }^{51}$ as it will alter the currency composition of reserves and create a currency exposure against the benchmark or the hedged position. If this exposure were to exceed a pre-determined threshold, a reserve manager would transact in the underlying currencies to return to the benchmark or to the hedged position. But these transactions could open a foreign exchange exposure because, from the whole balance sheet perspective, the exposure did not initially exist. Hence, hedging should be based on the net SDR position. ${ }^{52}$

\section{Interest Rate Risk}

\section{The new SDR allocation per se will not affect the interest rate risk of the foreign} reserves portfolio, but the use of SDRs does carry interest rate risk. SDR interest is effectively earned or paid only on the net SDR position (allocations minus holdings). Interest rate risk exposure only arises on a net basis (i.e., a net open position), when there is a difference between SDR holdings and cumulative allocations.

61. For a net SDR position, duration risk is negligible. The SDR interest rate is determined weekly using a weighted average of representative interest rates on three-month debt in the money markets of the five SDR basket currencies. This means that a net SDR position effectively is a floating rate deposit with weekly resets, making the most commonly used interest rate risk measureduration - to be one week. Moreover, the current floor of 5 basis points on the SDR interest rate provides additional diversification benefits in the context of foreign reserves' overall interest rate risk.

\section{However, as with other short duration assets or liabilities, the re-investment or re-} financing risk can be significant. Hence, an increase in interest rates could adversely impact those members with SDR holdings less than their cumulative SDR allocations, and reserve managers need

\footnotetext{
${ }^{51}$ The two main approaches to reserve currency composition design are asset-liability management and portfolio management. At the macro-level, asset-liability management aims at reducing the risks related to the country's balance of payments by matching the currency composition of reserves with those of imports and external debt, while the portfolio management uses mean variance optimization without currency all ocation constraints.

52 For many LIC central banks, using foreign exchange derivatives for hedging is not feasible due to the lack of capacity and counterparty relationships. In those cases, the foreign exchange risk implications of the asset-liability management strategy will become more relevant in managing the risks arising from the balance of payments and external debt.
} 
to consider overall asset and liability management practices to offset such risks. In addition, the overall duration of the portfolio would need to be set consistent with the overall objectives for reserve management.

\section{Credit Risk}

63. A positive net holding of SDRs might be viewed as a credit risk exposure to the other participants of the SDR Department. However, these exposures are usually excluded from the credit risk management framework. The value of the SDR as a reserve asset derives from the commitments of participants to hold and accept SDRs and to honor various obligations connected with the proper functioning of the SDR Department. ${ }^{53}$ In any event, these potential exposures to members of the SDR Department are typically larger than would be allowed for any other single entity, and a risk manager cannot actively manage them as they result directly from participation in the SDR Department.

\section{IMPLICATIONS FOR FUND-SUPPORTED PROGRAMS}

64. IMF engagement in program contexts should continue to focus on policies to restore macroeconomic sustainability and needed macroeconomic adjustments supported by a mix of financing. SDRs can help smooth needed adjustment and avoid distortionary policies but should not substitute nor delay appropriate macroeconomic adjustment and reforms. The allocation should not affect burden-sharing to support the catalytic role of the Fund. ${ }^{54}$

65. The SDR allocation will generally require an update of Fund-supported programs, particularly a fresh look at reserve adequacy and macroeconomic policies. The appropriate use of the increased SDR holdings resulting from the allocation, including balancing the need for higher reserves and for smoothing of external adjustment or urgent financing needs, should be decided on a case-by-case basis. Any changes to the program that are warranted by the SDR allocation would normally be done at the program review following the effectiveness date of the SDR allocation. Several macroeconomic principles apply:

- Different institutional arrangements should not lead to different macroeconomic advice across member countries. Staff's advice on the prudent use of the policy space provided by the allocation, as well as program modalities, should not depend on where members record the SDR allocation. However, possible constraints on the use of SDRs arising from institutional arrangements of the member would need to be considered.

- Countries should neither be penalized nor rewarded for having programs in place at the time of the allocation. The allocation should encourage a fresh look at reserve adequacy, the

\footnotetext{
53 The SDR is a potential claim on the freely usable currencies of IMF members and is not a claim on the IMF.

54 If other sources of financing were reduced, this would undermine the intent of the allocation to meet long -term global reserve needs and, with it, provide liquidity for all members.
} 
policy mix, and quantitative targets in current program cases, as it would for a country seeking to initiate a Fund program after the allocation.

- Direct limits on the use of SDR holdings are inconsistent with their status as an unconditional reserve asset, but program targets may indirectly result in limits (see Box 1). De facto limitations on the use of SDR holdings or other reserves could result from conditionality related to NIR or net domestic assets of the central bank necessary to meet the underlying objectives of the program, which generally would not be fundamentally affected by the allocation.

- Staff's underlying assessment of reserve adequacy and the need for increased precautionary reserves versus use of SDRs to meet financing needs should inform the degree to which program targets should be adjusted following the SDR allocation. In some cases, particularly in programs where a primary objective is to accumulate reserves and build buffers, the increase in reserves resulting from the allocation, absent any other urgent financing need, could affect the member's underlying balance of payment need (see paragraph 67 on access).

- Similarly, in cases where debt treatment (e.g., a restructuring or reprofiling) is needed, the allocation should not substitute for such restructuring if debt is unsustainable, or if debt is sustainable but there is a financing gap not fully covered by additional SDRs (see sections on macroeconomic implications and debt sustainability).

66. In the case of LICs, the SDR allocation should not be seen as a substitute for programbased concessional Fund financial support. Given the low interest cost of Fund concessional financing and the risk of a rising SDR interest rate (see section on reserve management and Figure 1), financing through one of the Fund's concessional facilities may be financially more favorable than the use of the SDR holdings. To meet new or increased balance of payments needs, larger access under a concessional Fund arrangement would thus generally be more appropriate than use of SDRs and drawing down reserves below adequate levels. If the need is urgent, SDRs could however usefully serve as a bridge until concessional financing is arranged.

67. Access to financing under Fund arrangements will continue to be guided by the established criteria while taking into account the impact of the SDR allocation. Access (both under the GRA and PRGT) is determined by: (i) the member's actual or potential balance of payments need for resources from the Fund; (ii) ability of the member to service its indebtedness to the Fund, including the strength of the adjustment program; and (iii) the member's outstanding use of Fund credit and its record in using Fund resources in the past.

68. By increasing reserves, the SDR allocation will generally tend to reduce a member's balance of payments need and may therefore have an impact on the determination of access. However, there are exceptions to the potential reduction in balance of payments need (e.g., domestic restrictions on central bank on-lending), and there is no presumption that SDRs would alone justify a 
lower level of access or early repayments under individual Fund arrangements. ${ }^{55} \mathrm{~A}$ higher level of reserves (or increased absorption) may well be justified in the context of increased economic risks or spillovers from the pandemic or otherwise changing country circumstances. In some cases, such as where a member seeks a Fund-supported program to strengthen its reserve position, SDRs could substitute for program support. When contemplating increased absorption, due consideration should be given to the general macroeconomic implications and institutional frameworks.

\section{Technical memoranda of understanding (TMU) should clarify the implications of the} SDR allocation for program performance criteria. Specifically, the effect on NIR would depend on the definition of the liabilities that are netted off in its formulation. As noted in the statistical and accounting implications section, SDR holdings are included in the reserve assets (gross reserves) within NIR, but there is some variation across TMUs concerning the liabilities that are to be deducted to derive program NIR. Most frequently, TMUs only deduct short-term liabilities and liabilities to the IMF, which would exclude the long-term SDR liabilities, and hence, program NIR would generally increase due to the allocation.

70. SDR liabilities are not subject to debt limits in IMF programs, whether used or not. SDR liabilities do not fall within the definition of "debt" for program purposes under the Fund's Guidelines on Public Debt Conditionality in Fund Arrangements. Unlike debt subject to debt limits, SDR liabilities are not created under a contractual arrangement, they do not mature, and they generally have limited impact on members' debt sustainability. ${ }^{56}$ This treatment is consistent with objectives of such limits to help address debt vulnerabilities by preventing an unsustainable build-up of external debt during the period of the Fund arrangement that may lead to debt-servicing problems in the medium term. It is also consistent with the treatment of IMF financing, which is excluded from debt limits to facilitate the use of IMF resources.

\footnotetext{
55 In any case, the Fund cannot unilaterally reduce access under existing arrangements, nor can it call for early repurchases of GRA credit other than in very narrowly specified circumstances. There are also additional requirements for decreases in access under PRGT arrangements, including that the improvement in the member's balance of payments justifying the decrease must derive in particular from improvements in the external environment.

${ }^{56}$ The long-term liabilities associated with the SDR allocation are treated differently from a statistical perspective (see section on statistical considerations and Annex I) than from a program and debt sustainability perspective. Regarding program and DSA treatment, as noted above and in paragraph 35, SDRs are treated similarly to Fund financing: they are excluded from the debt limits, but their usage is included in the DSA. Also see Guidance Note on Implementing the Debt Limits Policy in Fund Supported Programs and Limits on External Debt or Borrowing in Fund ArrangementsProposed Change in the Coverage of Debt Limits.
} 


\section{Annex I. Additional Statistical Considerations}

1. The BPM6 requires a liability to be recorded in the IIP for allocations of SDRs and an asset to be recorded for the holdings of SDRs (reserve assets). When new SDRs are allocated, the BPM6 requires transactions to be recorded in holdings of SDRs (reserve assets) and in allocations of SDRs (other investment liabilities). Further, accrued interest on holdings of SDRs (credit) and on allocations of SDRs (debit) are recorded on a gross basis in the primary income account. This treatment is consistent across macroeconomic statistics manuals and guides. A summary of the treatment in the current manuals is shown in Table 1.

\begin{tabular}{|c|c|c|c|c|}
\hline $\begin{array}{l}\text { Statistical } \\
\text { Manual }\end{array}$ & $\begin{array}{l}\text { Are SDR holdings } \\
\text { shown in } \\
\text { positions? }\end{array}$ & $\begin{array}{l}\text { Are SDR } \\
\text { allocations } \\
\text { shown in } \\
\text { positions? }\end{array}$ & $\begin{array}{c}\text { Are transactions or "other flows" } \\
\text { (valuation adjustments) } \\
\text { recorded? }\end{array}$ & $\begin{array}{l}\text { On what } \\
\text { basis is } \\
\text { interest } \\
\text { recorded? }\end{array}$ \\
\hline BPM6 & $\begin{array}{l}\text { Yes, as part of the } \\
\text { official reserve } \\
\text { assets. }\end{array}$ & $\begin{array}{l}\text { Yes, as long-term } \\
\text { debt liabilities. }\end{array}$ & $\begin{array}{l}\text { Financial account transactions (not } \\
\text { valuation adjustments) in assets and } \\
\text { liabilities after each new allocation } \\
\text { and subsequent use. }\end{array}$ & $\begin{array}{l}\text { Gross, for } \\
\text { holdings and } \\
\text { allocations } \\
\text { separately. }\end{array}$ \\
\hline $\begin{array}{l}\text { MFSMCG } \\
2016\end{array}$ & $\begin{array}{l}\text { Yes, as holdings of } \\
\text { SDRs (part of } \\
\text { "monetary gold and } \\
\text { SDRs") in assets. }\end{array}$ & $\begin{array}{l}\text { Yes, as debt } \\
\text { liabilities. }\end{array}$ & $\begin{array}{l}\text { New allocations are recorded in } \\
\text { positions on the liability side (debt } \\
\text { liability) and on the asset side, in } \\
\text { "SDRs". Transactions in assets and } \\
\text { liabilities (not valuation adjustments) } \\
\text { are recorded for each new allocation } \\
\text { and subsequent use. }\end{array}$ & $\begin{array}{l}\text { Gross, for } \\
\text { holdings and } \\
\text { allocations } \\
\text { separately. }\end{array}$ \\
\hline GFSM 2014 & $\begin{array}{l}\text { Yes, if held by } \\
\text { general } \\
\text { government, as } \\
\text { holdings of SDRs } \\
\text { (part of "monetary } \\
\text { gold and SDRs") in } \\
\text { financial assets. }\end{array}$ & $\begin{array}{l}\text { Yes, as debt } \\
\text { liabilities if SDRs } \\
\text { are recorded as } \\
\text { allocated to the } \\
\text { general } \\
\text { government. }\end{array}$ & $\begin{array}{l}\text { If SDRs are recorded on the balance } \\
\text { sheet of the general government, } \\
\text { financial account transactions (not } \\
\text { valuation adjustments) in assets and } \\
\text { liabilities after each new allocation } \\
\text { and subsequent use. }\end{array}$ & $\begin{array}{l}\text { If SDRs are } \\
\text { recorded on } \\
\text { the balance } \\
\text { sheet of the } \\
\text { general } \\
\text { government, } \\
\text { gross, for } \\
\text { holdings and } \\
\text { allocations } \\
\text { separately. }\end{array}$ \\
\hline $\begin{array}{c}2013 \text { EDS } \\
\text { Guide }\end{array}$ & $\begin{array}{l}\text { Not applicable } \\
\text { (only includes SDR } \\
\text { holdings as debt } \\
\text { instrument assets } \\
\text { in net external debt } \\
\text { presentation) }\end{array}$ & $\begin{array}{l}\text { Yes, as debt } \\
\text { liabilities. }\end{array}$ & Treatment as in BPM6. & Gross basis. \\
\hline $\begin{array}{l}2013 \text { IRFCL } \\
\text { Guidelines }\end{array}$ & $\begin{array}{l}\text { Yes, as part of the } \\
\text { official reserve } \\
\text { assets. }\end{array}$ & $\begin{array}{l}\text { Yes, as debt } \\
\text { liability. }\end{array}$ & Consistent with BPM6. & Gross basis \\
\hline
\end{tabular}


2. In the External Sector Statistics, the August 2021 increase in gross reserve assets due to the SDR allocation will be initially reflected in the monthly International Liquidity data presented in the October 2021 issue of the IFS. The 2021:Q3 balance of payments transactions and IIP positions data will reflect the new SDR allocation and the SDR holdings, starting with the January 2022 issue of the IFS (for countries compiling and reporting ESS on a quarterly basis). The 2021 edition of the BOPSY will also reflect these data. Furthermore, the increase in SDR holdings will be reflected in the Data Template on International Reserves and Foreign Currency Liquidity (Reserves Template), which is a data requirement for members subscribing to the Special Data Dissemination Standards (SDDS) - 13 non-SDDS members also report these data on a voluntary basis.

3. In monetary and financial statistics (MFS) as published in the IFS, the new SDR allocation will increase claims on nonresidents (foreign assets) and liabilities to nonresidents (foreign liabilities) for those countries where the SDR positions are included in the central bank's balance sheet. These changes will be reflected for the first time in the October 2021 issue of the IFS.

4. In GFS, if SDR allocations are held on the balance sheet of general government (e.g., by a government agency), the new allocation of SDRs will be classified as a debt liability to nonresidents, with a corresponding entry on the financial assets side (the SDR holdings). This will be reflected in the IFS starting with August 2021 data (released in the October 2021 issue) or Q3:2021 data (released in the January 2022 issue), depending on the frequency of data reported by countries. In line with the BPM6, the gross external debt position of member countries should also reflect the new SDR allocation. Tables disseminated on the IMF/World Bank Quarterly External Debt Statistics (QEDS) database website and Quarterly Public Sector Debt Statistics (QPSDS) database websites and the Joint External Debt Hub (JEDH) will reflect the new SDR allocation by January 2021.

\section{Specific Statistical Recording Issues}

5. Table 2 shows the specific BPM6 balance of payments and IIP items affected at the inception of the new SDR allocation. It illustrates the recording for both the standard and the analytic presentation of the balance of payments. The latter presents how the below-the-line itemsnamely, reserves assets, IMF credits and loans and exceptional financing - are used to finance the other "autonomous" international transactions. As defined by the BPM6, exceptional financing brings together financial arrangements made by the authorities (or by other sectors fostered by authorities) of an economy to meet balance of payments needs, such as accumulation of arrears, debt forgiveness, intergovernmental grants, and debt restructuring. SDR allocations (liabilities) are not considered as exceptional financing transactions.

6. As unconditional reserve assets, the SDR holdings resulting from the new allocation can be freely exchanged and may be used by members for purposes other than a balance of payments need, such as budget financing. Depending on the domestic legal and institutional arrangements in each member country, the central bank or any other public entity holding the SDR positions in its balance sheet may be entitled to use or on-lend such resources to other government units. In such cases, the on lender will still hold the SDR allocation position as an external debt 
liability and will have a domestic claim on the recipient government unit. If intersectoral consolidation is conducted, the reciprocal domestic positions between the two public entities will be excluded, and only the external debt liability—the SDR allocation-reflected in the total public external debt.

Table 2. Recording of SDR Allocations and Holdings and Related ltems in BPM6

\begin{tabular}{|c|c|c|c|c|}
\hline \multirow{2}{*}{ Balance of Payments Items } & \multicolumn{2}{|c|}{$\begin{array}{c}\text { Standard } \\
\text { Presentation }\end{array}$} & \multicolumn{2}{|c|}{$\begin{array}{c}\text { Analytic } \\
\text { Presentation }\end{array}$} \\
\hline & Credits & Debits & Credits & Debits \\
\hline $\begin{array}{l}\text { Current account } \\
\text { Primary income } \\
\text { Other Investment-Interest: Accrued Interest on total } \\
\text { SDR Allocations } \\
\text { Reserve assets-Interest: Accrued Interest on total SDR } \\
\text { Holdings } \\
\text { Capital account }\end{array}$ & B & A & B & $A$ \\
\hline & NAFA & $\mathrm{NIL}$ & NAFA & $\mathrm{NIL}$ \\
\hline $\begin{array}{l}\text { Financial account } \\
\text { Other investment } \\
\text { Allocation of SDRs } \\
\text { Reserves assets } \\
\text { Holdings of SDRs }\end{array}$ & & C & & C \\
\hline & \multicolumn{2}{|c|}{ Memorandum items } & \multicolumn{2}{|c|}{ "Below the line" } \\
\hline Reserves and related items & Credits & Debits & Credits & Debits \\
\hline $\begin{array}{l}\text { I. Reserve Assets } \\
\text { II. IMF Credit and loans } \\
\text { III. Exceptional financing }\end{array}$ & & & $\mathrm{C}$ & \\
\hline \multirow{2}{*}{\multicolumn{5}{|c|}{\begin{tabular}{c|c|} 
NAFA $=$ net acquisition of financial assets; $\mathrm{NIL}=$ net incurrence of liabilities \\
IIP Position Items & Assets
\end{tabular}}} \\
\hline & & & & \\
\hline $\begin{array}{l}\text { Net IIP } \\
\text { Other investment } \\
\text { Allocation of SDRs } \\
\text { Reserves assets } \\
\text { Holdings of SDRs }\end{array}$ & $\mathrm{E}$ & $\mathrm{D}$ & & \\
\hline
\end{tabular}




\section{Annex II. Reconstitution Requirements for SDR Holdings}

1. Reconstitution requirements for holdings of SDRs were established with the introduction of the SDR but were abrogated in 1981. The Executive Board could, with a 70 percent majority of the total voting power, re-establish the same rules or adopt different reconstitution rules.

\section{Main Rationale}

2. The original reconstitution requirement reflected the desire to ensure that the new liquidity resulting from the creation of SDRs would not be used to finance prolonged balance of payments deficits, generating a permanent transfer of real resources from countries that accumulate SDRs to countries that use them on a net basis. The concern about the size of such transfers was greater in the past because the SDR interest rate was previously set below market interest rates.

\section{Rules of Reconstitution}

\section{From 1969 to 1981}

3. The first of the rules was that a participant in the SDR Department must maintain its average daily holdings of SDRs at not less than a specified percentage of its average net cumulative allocation over successive five-year periods ending each calendar quarter. That percentage was 30 until January 1, 1979 when it was reduced to 15, at the same time that the SDR interest rate was raised from 60 percent of the combined market interest rate (a weighted average yield of short-term money market rates) to 80 percent.

4. The rule allowed a participant to use all its SDRs, but if it did so it would need eventually to reconstitute its holdings by acquiring an amount of SDRs sufficient to increase its average daily holdings to the required minimum. Countries experiencing severe shortages of foreign exchange sometimes had difficulties in complying with the reconstitution requirements, which were generally considered complex by participants. To help participants meet the reconstitution requirement, the Executive Board decided, in December 1971, that participants with a need to acquire SDRs could do so from the GRA, or from another participant, enabling them to acquire SDRs at a time of their choosing rather than by being designated to receive them, possibly at a difficult juncture.

5. The second rule for reconstitution required participants to "pay due regard to the desirability of pursuing over time a balanced relationship between their holdings of special drawing rights and their other reserves." During the period when this rule was in place, the Fund did not elaborate any criteria by which observance of this rule could be tested. 
After 1981

6. Reflecting the increase of the SDR interest rate to the level of the combined market rate (effective May 1, 1981), the enhanced liquidity of the SDR, including via voluntary SDR trading agreements, and the perceived complexity of the reconstitution mechanism, the reconstitution requirement was abrogated, effective April 30, 1981. 


\section{Annex III. SDR Department}

1. The SDR Department is separate from the General Department and all other accounts of, or administered by, the Fund under the Articles of Agreement. The resources in the SDR Department cannot be used to meet the liabilities, obligations, or losses of the IMF, incurred in the operations of the General Department or other accounts, except that the General Department is reimbursed for the expenses incurred in conducting the business of the SDR Department. ${ }^{1}$

2. SDRs may be held and used by participants in the SDR Department and certain official entities prescribed as other holders by the Fund in accordance with the Articles of Agreement and decisions adopted by the Fund (see Box 1). The IMF has the authority to prescribe, as other holders of SDRs, nonmembers, member countries that are not SDR Department participants, institutions that perform the functions of a central bank for more than one member, and other official entities. Currently there are 15 prescribed holders in the SDR department. ${ }^{2}$ These prescribed holders may acquire and use SDRs in transactions by agreement and in operations with participants and other holders. They may not, however, receive allocations of SDR.

\section{The Fund has adopted a number of decisions that authorize a broad range of} operations among participants and prescribed holders in the SDR Department. These include loans, settlement of financial obligations, swaps, pledges, transfer and retransfer agreements, forward operations, and donations. . $^{3,4}$

4. The SDR Department keeps record of members' SDR allocations and holdings; it is also the channel through which all transactions and operations involving SDRs are conducted. When SDRs are allocated to SDR Department participants in a general or special allocation, the Department records an increase in the participants SDR holdings and allocations (see accounting section). Participants' cumulative allocations remain unchanged as long as the participant remains a member of the SDR Department and there is no cancellation of SDRs, which so far has not taken

\footnotetext{
${ }^{1}$ The expenses of conducting the business of the SDR Department are paid by the IMF from the GRA, which is reimbursed annually by the SDR Department. For this purpose, the SDR Department levies an assessment on all participants in proportion to their cumulative allocations at the end of each financial year on April 30. The rate is determined annually by the IMF's Executive Board based on the administrative expense for the given year.

${ }^{2}$ The 15 prescribed holders are four central banks (European Central Bank, Bank of Central African States, Central Bank of West African States, and Eastern Caribbean Central Bank); three intergovernmental monetary institutions (Bank for International Settlements, Latin American Reserve Fund, and Arab Monetary Fund); and eight development institutions (African Development Bank, African Development Fund, Asian Development Bank, International Bank for Reconstruction and Development, International Development Association, Islamic Development Bank, Nordic Investment Bank, and International Fund for Agricultural Development).

${ }^{3}$ Article XIX Section 2 (c). Rule P-7. By mutual agreement, official holders of SDRs (excluding the IMF itself) may enter into other prescribed operations including the settlement of financial obligations, subject only to the equal -value principle. Therefore, official holders may freely transfer SDRs to other official holders to settle financial obligations such as repayments of loans or payments of interest.

${ }^{4}$ In practice, the bulk of SDR transactions consist of spot sales/purchases of SDRs against freely usable currencies.
} 


\section{Box 1. SDR Transactions and Operations}

A participant in the SDR Department or prescribed holder may use SDRs freely, without the requirement of a balance of payments need, to obtain an equivalent amount of currency in a transaction by agreement with another participant or prescribed holder. These transactions can be facilitated by the Fund through the VTAs or arranged bilaterally between two parties:

- VTAs are arrangements between the Fund and a group of 31 SDR participants and one prescribed holder as of June 30,2021 who have agreed to exchange SDRs for specific currencies within set limits. ${ }^{1}$

- In bilateral agreements, SDR participants or prescribed holders agree among themselves to buy or sell SDRs bilaterally. Both parties to a voluntary bilateral trade inform the IMF about the terms of the trade by sending requests from their fiscal agents, including the proposed value date. The IMF official exchange rates are used for these trades. ${ }^{2}$

For over three decades, most transactions have been arranged through the VTA market with a few transactions agreed bilaterally between participants and/or prescribed holders in the SDR Department.

In the rare event that a participant with a balance of payments need seeks to exchange its SDRs, but a counterparty could not be identified either bilaterally or through the VTAs, or if the VTA capacity were to be insufficient, the designation mechanism under the Fund's Articles of Agreement (Article XIX) can be activated. Under the designation mechanism, the SDR Department can call upon members with sufficiently strong external positions to provide freely usable currency in exchange for SDRs from the requesting participant who represents a balance of payments need. Since 1987, there has been no need to use this mechanism. A designation plan is prepared annually for Executive Board approval and has been precautionary.

Participants in the SDR Department can request exchange of SDRs into currencies/currencies into SDRs via the VTAs by sending an authenticated request from the fiscal agent of the member to the IMF. The request should be sent at least seven business days ahead of the proposed transaction date to ensure that VTA participants can receive advance notification as stipulated in their arrangements. The request should include the amount to be purchased or sold, currency preference, value date, and settlement banking details (for the exchange of SDRs into currencies). While Finance Department staff will take into account the currency preference of the requestor, ultimately the currency for the transaction will be influenced by the freely usable currencies available in the VTA market. Finance Department staff will confirm the completion of the transaction and record the relevant debits and credits when the party receiving currency confirms the receipt. All transactions in the SDR Department take effect after they are recorded by the Finance Department (see timeline below).

\section{Timeline for SDR Transactions through VTAs}

\begin{tabular}{|c|c|}
\hline Days & Events \\
\hline$T-7$ & $\begin{array}{l}\text { The fiscal agent of the SDR Department participant or prescribed holder notifies the IMF } \\
\text { about its intention to buy or sell SDRs. Longer lead times may be required if finding a willing } \\
\text { counterpart is uncertain. }\end{array}$ \\
\hline$T-5$ & $\begin{array}{l}\text { The IMF selects a VTA counterparty and dispatches advance notification communication via } \\
\text { SWIFT to both buyer and seller. This advance notification period is stipulated in the VTAs. }\end{array}$ \\
\hline$T-2$ & $\begin{array}{l}\text { The IMF provides payment instructions to the counterparty provid ing the currency and } \\
\text { notifies the party receiving the payment. }\end{array}$ \\
\hline $\boldsymbol{T}$ & Value Date \\
\hline$T$ or $T+1$ & SDR seller confirms receipt of currency to the IMF. \\
\hline$T$ or $T+1$ & The IMF confirms a debit to the SDR seller. \\
\hline$T$ or $T+1$ & The IMF confirms a cred it to the SDR buyer. \\
\hline
\end{tabular}

${ }^{1}$ Finance Department staff operates as a market maker to facilitate the exchanges of SDRs under the VTAs between participants who want to buy or sell SDRs. In bilateral transactions, the Finance Department does not play a market maker role.

${ }^{2}$ For information on SDR valuation, see https://www.imf.org/external/np/fin/data/rms sdrv.aspx. 
place in the history of the Fund. Members' holdings will increase or decrease over time as participants either use SDRs within the broad range of permitted operations, including with the Fund or when they acquire or sell SDRs. Holdings below allocations result in a net positive SDR position in the SDR Department balance sheet, while holdings above allocations result in a net negative SDR position in the SDR Department. The SDR Department also has a liability to the GRA and the prescribed holders on their SDR holdings.

\section{The structure of the SDR Department is self-financed, and its basic structure is} relatively straightforward (Figure 1). It charges interest on participants' SDR allocations at the same rate as the interest paid on their SDR holdings. Participants that use their SDRs will pay more charges than they will receive interest on their holdings, to the extent that they hold fewer SDRs than their cumulative allocations. Conversely, participants that hold more SDRs than their cumulative allocations will receive more interest on their holdings than the charges they will pay on their allocations. Overall, interest payments and receipts in the SDR Department among all participants normally cancel out-i.e., it is a "closed system." ${ }^{5}$ Interest and charges accrue daily. The amounts accrued for the quarter are settled at the beginning of the following quarter in accordance with the IMF's rules. A standing authorization to debit a participant's SDR holdings is not required for settlement of charges payable to the SDR Department. ${ }^{6,7}$ The Fund determines the SDR interest weekly based on a weighted average of representative interest rates on three-month debt in the money markets of the SDR basket currencies. $8,9,10$

\section{Participants can use their SDRs in a wide range of Fund-related operations. The Fund} may accept and use SDRs in operations and transactions conducted through the GRA with participants (e.g., quota payments, purchases, repurchases, payment of charges, remuneration) and the Fund may pay principal and interest on its borrowing in SDRs. For example, the Fund normally receives SDRs in members' payments of charges on Fund credit and pays SDRs to members in remuneration on their reserve tranche positions in the Fund. In addition, the Fund has authorized the use of SDRs in operations of the PRGT, the Poverty Reduction and Growth (PRG)-Heavily Indebted Poor Countries (HIPC) Trust and the Catastrophe Containment and Relief Trust (CCRT) (e.g., borrowing, loan disbursements, interest payments, or contributions) (Box 2.)

\footnotetext{
${ }^{5}$ Note that in the case of interest arrears by a participant, additional SDRs are temporarily created to pay interest to members with holdings above allocation. These SDRs are then cancelled once the interest arrears have been cleared.

${ }^{6}$ Article XX, Sections 1-3 and 5. Rule T-1.

${ }^{7}$ Accrued and paid SDR interest and charges are published on a monthly basis on secure member portal "Finance Connect": https://www-mfs.imf.org.

${ }^{8}$ The basket currencies include the U.S. dollar, Japanese yen, euro, Chinese Renminbi and pound sterling.

${ }^{9}$ The weekly SDR interest rate can be found here: weekly SDR interest rate.

10 The rules for the computation and the historical data for the SDR interest rate could be found at https://www.imf.org/external/np/fin/data/query.aspx.
} 


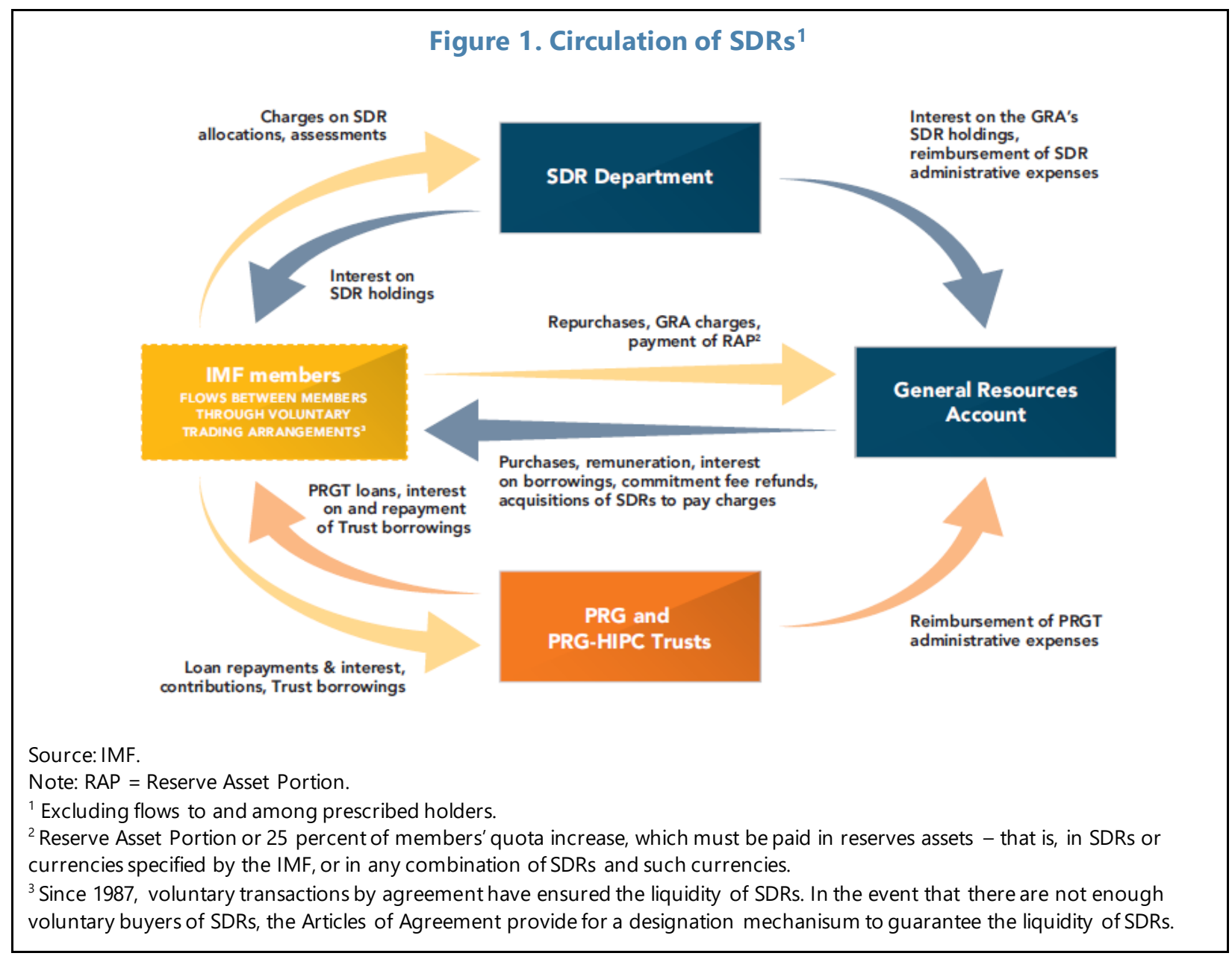

\section{Participants can fall into arrears in the SDR Department if they do not have sufficient}

SDRs to meet Fund obligations. ${ }^{11}$ While there is currently no requirement for minimum holdings of SDRs, it is the member's obligation to ensure that it has sufficient SDRs in its holdings to meet its obligations to the Fund payable in SDRs (including obligations to the GRA, SDR Department, and the PRGT). ${ }^{12}$ In the event that a member falls into arrears to the SDR Department (see Procedures for Dealing with Members with Overdue Financial Obligations to the General Department and the SDR Department), measures will be taken in line with the Fund's strategy on overdue financial obligations. In particular, immediately the member would not be permitted to use any Fund resources (i.e., GRA or Trust resources), and measures would then be escalated as time passes. ${ }^{13}$ Participants should monitor movements in their SDR holdings using various resources provided by the Fund to ensure

\footnotetext{
${ }^{11}$ If sufficient SDRs are not received from the participant because charges are overdue, additional SDRs are temporarily created. This is a receivable that is reversed when the participant settles the overdue charges.

${ }^{12}$ It is strongly recommended that the member provides a standing authorization to the IMF to debit its SDR holdings account for all upcoming obligations to the IMF, such as fees, charges on GRA and PRGT financing, GRA repurchases, and PRGT loan repayments. A standing authorization is not required for settlement of charges payable to the SDR Department as under the Articles the Fund automatically debits members SDR holdings with charges accrued.
}

13 See Decision No 12546-(01/84) 
they have sufficient SDRs to meet upcoming financial obligations. Many participants acquire SDRs on a regular basis to ensure they have sufficient SDRs.

Box 2. Summary of SDR-Related Fund Operations

SDRs are used in a variety of Fund-related transactions in the SDR Department, GRA operations, and concessional lending and debt relief trust operations (PRGT, the PRG-HIPC Trust and the CCRT):

SDR Department Operations

- Use of SDR to pay assessments and charges on SDR allocation/receipt of SDR interest

- Transactions (sale and purchase of SDRs) and other operations among SDR participants and prescribed holders, as authorized under the Articles and relevant decisions by the Fund adopted in accordance with the Articles.

GRA Operations

- Quota payments: In general, 25 percent of quota subscription is payable by each member to the Fund in SDRs or currency of another member as determined by the Fund and the remainder is due in the member's own currency.

- Purchases and repurchases in the GRA: IMF financing is conducted via a purchase and repurchase mechanism. Purchases by members of SDRs in the GRA and repurchases by members using SDRs as payments.

- Acquisitions in exchange forcurrencies of other members: Acquisitions of SDRs from the GRA in exchange for currencies of other members.

- Repayment of GRA borrowings and interest: Repayments of principal and payment of interest under New Arrangements to Borrow and Bilateral Borrowing Arrangements.

- GRA charges and Remuneration: GRA charges are payable in SDRs. ${ }^{1}$ Such charges are accrued daily and billed quarterly. Members also receive remuneration on their reserve tranche position in the GRA, on a quarterly basis, if applicable.

- Service charges: A service charge of 50 basis points is levied on each purchase (disbursement to a member) from the GRA and is payable in SDRs on the date of the purchase.

- Commitment fees: Commitment fee is levied by the IMF in SDRs, as a fee for the amounts available for purchase under the GRA arrangement at each 12 -month period of an arrangement. Commitment fee is refunded to a member as it makes purchases.

\section{Concessional Lending and Debt Relief Trust Operations}

Participants and prescribed holders are authorized to conduct transfers of SDRs in effecting transactions in connection with the financial operations of the Concessional Lending and Debt Relief Trusts (Trusts). These transactions mainly include PRGT pass-through lending involving participants in the SDR Department and interest payments on PRGT borrowing and lending. Other possible SDR transactions for the benefits of the Trusts include financial contributions provided by participants to the Trusts. Pursuant to the Fund's existing authorization, the Bank for International Settlements has been serving as the record-holder, and making transfers, of SDRs on behalf of the Trusts.

${ }^{1}$ GRA charges on credit outstanding comprise basic charges and surcharges, including possible burden sharing adjustments. 


\section{Annex IV. Useful Tools and Links to SDR Resources for Staff}

\begin{tabular}{|l|l|}
\hline \multicolumn{1}{|c|}{ Tool } & \multicolumn{1}{c|}{ Description and External Web Link } \\
\hline IMF Finances & SDR Allocations and Holdings by Member \\
\hline IMF FinancesiPad App & $\underline{\text { Aggregate and Member SDR Holdings }}$ \\
\hline IMF Financial Data Query Tool & $\begin{array}{l}\text { Across member SDR Allocations and Holdings, Projected and Historical net } \\
\text { SDR Charges and Assessments from 1984 }\end{array}$ \\
\hline Quarterly Financial Reports & $\begin{array}{l}\text { Aggregate Use of SDR Holdings and Statement of Changes, Allocations and } \\
\text { Holdings }\end{array}$ \\
\hline IMF Financial Operations 2018 & $\begin{array}{l}\text { Links basic Information on the SDR Department (See Sections 4.5 on the } \\
\text { Operation of the SDR Department including introduction on Voluntary }\end{array}$ \\
\hline $\begin{array}{l}\text { Trading Arrangement Market). This publication also provides extensive } \\
\text { information on the functioning of the VTA market and includes details on the }\end{array}$ \\
\hline $\begin{array}{l}\text { VTA operating modalities, capacity, trading by region and also covers } \\
\text { aggregate transaction volumes. }\end{array}$ \\
\hline SDR Interest rate & $\underline{\text { Weekly SDR interest rate }}$ \\
\hline
\end{tabular}




\section{References}

International Monetary Fund (IMF), 2008, "System of National Accounts, 2008," IMF Statistics Handbook, Washington DC.

International Monetary Fund (IMF), 2009a, "Balance of Payments and International Investment Position Manual (Sixth Edition)," IMF Statistics Handbook, Washington, DC.

International Monetary Fund (IMF), 2009b, "Guidance Note for Fund Staff on the Treatment and Use of SDR Allocations," IMF Policy Paper. Washington, DC.

International Monetary Fund (IMF), 2013a, "External Debt Statistics: Guide for Compilers and Users," IMF Statistics Handbook. Washington, DC.

International Monetary Fund (IMF), 2013b, "International Reserves and Foreign Currency Liquidity: Guidelines for a Data Template," IMF Statistics Handbook. Washington, DC.

International Monetary Fund (IMF), 2013c, "Staff Guidance Note on the Application of the Joint BankFund Debt Sustainability Framework for Low-Income Countries," IMF Policy Paper. Washington, DC.

International Monetary Fund (IMF), 2014, "Government Finance Statistics Manual," IMF Statistics Handbook. Washington, DC.

International Monetary Fund (IMF), 2016, "Monetary and Financial Statistics Manual and Compilation Guide," IMF Statistics Handbook. Washington, DC.

International Monetary Fund (IMF), 2018a, "Considerations on the Role of the SDR," IMF Policy Paper, Washington, DC.

International Monetary Fund (IMF), 2018b, "Guidance Note on the Bank-Fund Debt Sustainability Framework for Low Income Countries," IMF Policy Paper, Washington, DC.

International Monetary Fund (IMF), 2021a, "Proposal for a General Allocation of Special Drawing Rights," IMF Policy Paper, Washington, DC.

International Monetary Fund (IMF), 2021b, "Proposal by the Managing Director of the International Monetary Fund for an Allocation of Special Drawing Rights for the Eleventh Basic Period, Washington, DC. 